U.S. GEOLOGICAL SURVEY CIRCULAR 943

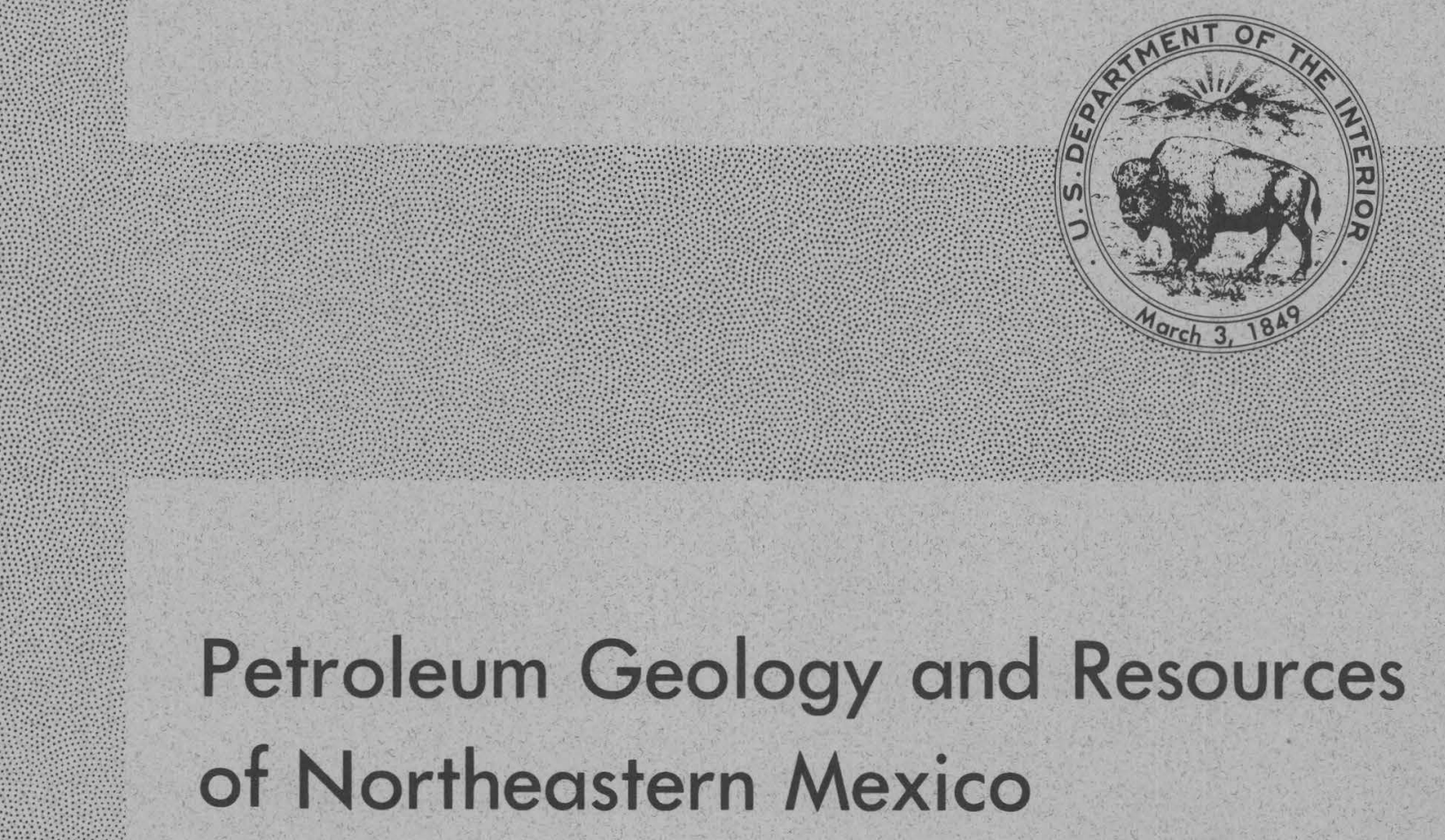

\section{Petroleum Geology and Resources of Northeastern Mexico}

$\operatorname{arch~} 3,18$

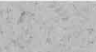

(

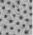

\section{.}

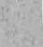

(n)

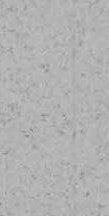

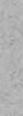





\section{Petroleum Geology and Resources of Northeastern Mexico}

By James A. Peterson

U.S. GEOLOGICAL SURVEY CIRCULAR 943

Potentially major petroleum deposits,

primarily gas, in northeastern

Mexico occur in carbonate and

clastic reservoirs of Cretaceous

and Jurassic age 


\section{DEPARTMENT OF THE INTERIOR DONALD PAUL HODEL, Secretary \\ U.S. GEOLOGICAL SURVEY Dallas L. Peck, Director}

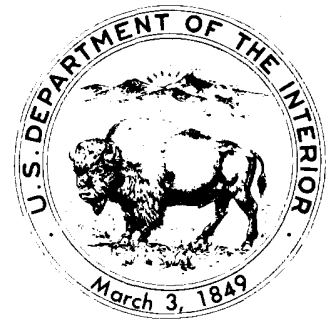

\section{Library of Congress Cataloging-in-Publication Data}

Peterson, James A.

Petroleum geology and resources of northeastern Mexico

(Geological Survey circular;943)

Bibliography:p. 27

Supt. of Docs. no. : I 19.4/2:943

1. Gas, Natural—Geology-Mexico. 2. Gas, Natural-Mexico. 3. Petroleum—Geology-Mexico. 4. Petroleum-Mexico. I. Title. II. Series.

TN882.M6P47 $1985 \quad 553.2^{\prime} 8^{\prime} 09721 \quad 85-600110$

Free on application to Distribution Branch, Text Products Section, U.S. Geological Survey, 604 South Pickett Street, Alexandria, VA 22304 


\section{PREFACE}

The World Energy Resources Program of the U.S. Geological Survey (USGS) intends to develop reliable and credible estimates of undiscovered recoverable petroleum resources throughout the world. Initial program efforts have focused on the major producing areas of the world in order to gain a broad understanding of the geologic characteristics of petroleum occurrence for purposes of resource assessment as well as for analysis of production potential. Investigations of production potential are carried out in cooperation with other U.S. Government agencies; specifically, the studies of the main free-world exporting nations, of which this study is a part, are carried out in cooperation with the Foreign Energy Supply Assessment Program of the Department of Energy. The estimates represent the views of a U.S. Geological Survey study team and should not be regarded as an official position of the U.S. Government.

The program seeks to investigate resource potential at the basin level, primarily through analogy with other petroleum regions, and does not necessarily require, therefore, current exploration information that is commonly held proprietary. In conducting the geological investigations, we intend to build a support base of publicly available data and regional geologic synthesis against which to measure the progress of exploration and thereby validate the assessment. Most of these investigations will lead directly to quantitative resource assessments; to be effective, resource assessment, like exploration, must be an ongoing process taking advantage of changing ideas and data availability - the results produced being progress reports reflecting a state of knowledge at a point in time. Because the program is coordinated with the USGS domestic assessment program and both utilize similar techniques for assessment, the user can be assured of a thread of consistency permitting comparisons between the various petroleum basins of the world, including those of the United States, that have been assessed in the overall USGS program.

In addition to resource estimates, the program provides a regional base of understanding for in-country exploration analysis and for analysis of media reports regarding the exploratory success or failure of ventures in studied areas.

USGS open-file reports related to the assessment of undiscovered conventionally recoverable petroleum resources include:

81-0986-Assessment of conventionally recoverable petroleum resources of Persian Gulf basin and Zagros fold belt (Arabian-Iranian basin)

81-1027-Assessment of conventionally recoverable petroleum resources, Volga-Urals basin, U.S.S.R.

81-1142-Assessment of conventionally recoverable petroleum resources of Indonesia

81-1143-Assessment of conventionally recoverable petroleum resources of northeastern Mexico

81-1144-Assessment of conventionally recoverable petroleum resources of southeastern Mexico, northern Guatemala, and Belize

81-1145-Assessment of conventionally recoverable petroleum resources of Trinidad

81-1146-Assessment of conventionally recoverable petroleum resources of Venezuela

81-1147-Assessment of conventionally recoverable petroleum resources of the West Siberian Basin and Kara Sea Basin, U.S.S.R.

81-0296-Assessment of undiscovered conventionally recoverable petroleum resources of the Middle Caspian basin, U.S.S.R.

82-1027-Assessment of undiscovered conventionally recoverable petroleum resources of the East Siberian Basin, U.S.S.R.

82-1056-Assessment of undiscovered conventionally recoverable petroleum resources of North Africa

82-1057-Assessment of undiscovered conventionally recoverable petroleum resources of the Timan-Pechora basin, U.S.S.R., and Barents-northern Kara shelf

83-0598-Assessment of undiscovered conventionally recoverable petroleum resources of northwestern, central, and northeastern Africa

83-0801-Assessment of undiscovered conventionally recoverable petroleum resources of onshore China 
84-0094-Assessment of undiscovered conventionally recoverable petroleum resources of the northwest European assessment region

84-0158-Assessment of undiscovered conventionally recoverable petroleum resources of New Zealand

84-0214-Assessment of undiscovered conventionally recoverable petroleum resources of Australia

84-0328-Assessment of undiscovered conventionally recoverable petroleum resources in Tertiary sedimentary basins of Malaysia, Brunei

84-0329-Assessment of undiscovered conventionally recoverable petroleum resources in offshore Tertiary sedimentary basins of The People's Republic of China

84-0330-Assessment of undiscovered conventionally recoverable petroleum resources in Tertiary sedimentary basins of Thailand

84-0852-Assessment of undiscovered conventionally recoverable petroleum resources of South Asia

These reports are available from Open File Services Section, Branch of Distribution, USGS, Box 25425, Federal Center, Denver, CO 80225. Prices are available on request.

USGS Circulars related to the assessment of undiscovered conventionally recoverable petroleum resources include:

C-760-Petroleum geology and resources of southeastern Mexico, northern Guatemala, and Belize

C-881-Assessment of undiscovered recoverable resources of the Arabian-Iranian basin

C-885-Petroleum geology and resources of the Volga-Urals province, U.S.S.R.

C-899-Assessment of undiscovered conventionally recoverable petroleum resources of Indonesia

C-922-A-Assessment of undiscovered conventionally recoverable petroleum resources of the Northwest European Region

Circulars are available free from the Distribution Branch, Text Products Section, U.S. Geological Survey, 604 South Pickett Street, Alexandria, VA 22304. 


\section{CONTENTS}

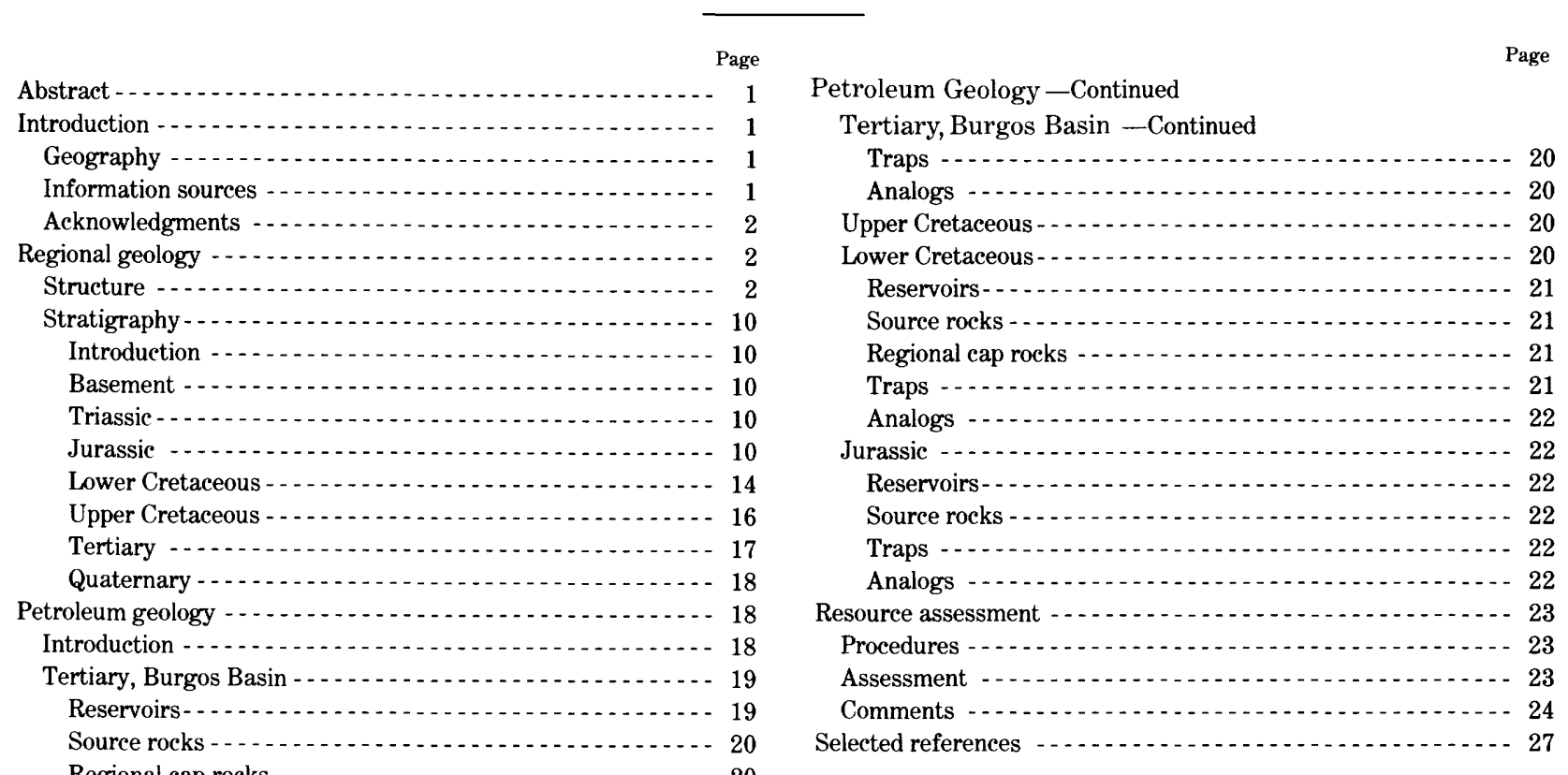

\section{ILLUSTRATIONS}

Figure

1. Index maps of northeastern Mexico showing main basins and uplifts and outline of assessment area

2. Stratigraphic correlation chart of northeastern Mexico and adjacent area - . . . -

3. Map of northeastern Mexico showing main structural features, oil and gas fields, important dry holes, and outcrop areas of Lower Cretaceous and Tertiary sedimentary rocks and Tertiary igneous rocks - . . . . . . . . . . .

4. Map of Mesozoic paleostructure showing regional basin and uplift features active during Jurassic and Cretaceous deposition - . . . . . . . . . . . . . . . .

5. North-south structural-stratigraphic cross section $A-A^{\prime}$, southwestern Texas to Sierra Madre Oriental south of Monterrey, Mexico, showing Cretaceous and Jurassic sedimentary facies, structural features, and productive intervals - - -

6. Southwest-northeast structural-stratigraphic cross section $B-B^{\prime}$, Sierra Madre Oriental south of Parras, Mexico, to Gulf Coast south of Corpus Christi, Tex., showing Cretaceous and Jurassic sedimentary facies, structural features, and

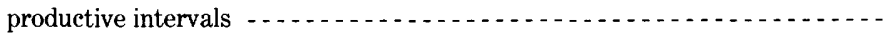

7. West-east structural-stratigraphic cross section $C-C^{\prime}$, Sabinas basin to Gulf Coast at mouth of Rio Grande, showing Cretaceous and Jurassic sedimentary facies, structural features, and productive intervals

8-12. Maps showing:

8. Approximate thickness in feet, partly restored, Jurassic System, and approximate distribution of pre-Oxfordian salt, postsalt Upper Jurassic main sedimentary facies, and gas fields producing from Upper Jurassic reservoirs - . 2 - .

9. Approximate thickness in feet, partly restored, Coahuilan Series, Lower Cretaceous, and main sedimentary facies and gas fields producing from rocks of

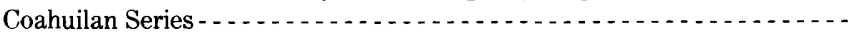

10. Approximate thickness in feet, partly restored, Comanchean Series, and main sedimentary facies and gas fields producing from rocks of Comanchean Series - . 
Figure 11. Approximate thickness in feet, partly restored, Gulfian Series and main sedimentary facies and gas and oil fields producing from rocks of Gulfian Series - . - -

12. Approximate thickness in thousands of feet, Tertiary System, and gas and oil fields producing from Tertiary rocks in Mexico and from productive trends in

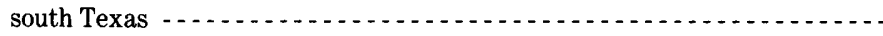

13-14. Graphs showing:

13. Aggregate recoverable oil in Burgos and Sabinas-Parras basins, Mexico - - . - -

14. Aggregate recoverable total gas in Burgos and Sabinas-Parras basins,

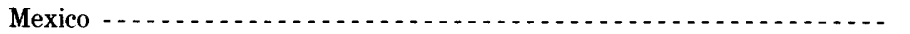

\title{
TABLES
}

1. Estimates of conventionally recoverable petroleum resources of northeastern Mexico, including those of the Sabinas, Parras, and Burgos basins . . . . . . . . 23

2. Data and information summary - .

3. Summary of assessment factors -

4. Supplementary and comparative data supporting the resource estimates for northeastern Mexico -

\section{ABBREVIATIONS USED IN THIS REPORT}

\author{
BBO-Billion barrels of oil \\ BBOE-Billion barrels of oil equivalent \\ BCF-Billion cubic feet \\ BD-Barrels per day \\ BOE-Barrels of oil equivalent \\ CFD-Cubic feet per day \\ MMBO-Million barrels of oil \\ MMCF-Million cubic feet \\ TCF_-Trillion cubic feet
}




\title{
Petroleum Geology and Resources of Northeastern Mexico
}

\author{
By James A. Peterson
}

\section{ABSTRACT}

Petroleum deposits (primarily gas) in northeastern Mexico occur in two main basins, the Tertiary Burgos basin and the Mesozoic Sabinas basin. About 90 gas fields are present in the Burgos basin, which has undergone active exploration for the past 30-40 years. Production in this basin is from Oligocene and Eocene nearshore marine and deltaic sandstone reservoirs. Most of the fields are small to medium in size on faulted anticlinal or domal structures, some of which may be related to deep-seated salt intrusion. Cumulative production from these fields is about 4 trillion cubic feet gas and 100 million barrels condensate and oil. Since 1975 , about 10 gas fields, some with large production rates, have been discovered in Cretaceous carbonate and Jurassic sandstone reservoirs in the Sabinas basin and adjacent Burro-Picachos platform areas. The Sabinas basin, which is in the early stages of exploration and development, may have potential for very large gas reserves.

The Sabinas basin is oriented northwesterly with a large number of elongate northwest- or west-trending asymmetric and overturned Laramide anticlines, most of which are faulted. Some of the structures may be related to movement of Jurassic salt or gypsum. Lower Cretaceous and in some cases Jurassic rocks are exposed in the centers of the larger anticlines, and Upper Cretaceous rocks are exposed in much of the remainder of the basin. A thick section of Upper Cretaceous clastic rocks is partly exposed in tightly folded and thrust-faulted structures of the west-east oriented, deeply subsided Parras basin, which lies south of the Sabinas basin and north of the Sierra Madre Oriental fold and thrust belt south and west of Monterrey.

The sedimentary cover of Cretaceous and Jurassic rocks in the Sabinas and Parras basins ranges from about $1,550 \mathrm{~m}(5,000 \mathrm{ft})$ to $9,000 \mathrm{~m}(30,000 \mathrm{ft})$ in thickness. Upper Jurassic rocks are composed of carbonate and dark organic shaly or sandy beds underlain by an unknown thickness of Late Jurassic and older redbed clastics and evaporites, including halite. Lower Cretaceous rocks are mainly platform carbonate and fine clastic beds with some evaporites (gypsum or anhydrite) deposited in two main rudist reef-bearing carbonate cycles. Upper Cretaceous rocks are mainly continental and marine clastic beds related to early development of the Laramide orogeny. This Upper Cretaceous sequence contains a marine shale and deltaic clastic complex as much as $6,000 \mathrm{~m}(20,000 \mathrm{ft})$ or more thick in the Parras basin, which grades northward and eastward to open marine, fine clastic beds. The Burgos basin, which is an extension of the Rio Grande embayment of the western Gulf of Mexico basin province, contains an eastward-thickening wedge of Tertiary continental and marine clastics. These beds are about 1,550 to $3,000 \mathrm{~m}$ $(5,000-10,000 \mathrm{ft})$ thick in the outcrop belt on the west side of the basin and thicken to more than $16,000 \mathrm{~m}(50,000 \mathrm{ft})$ near the Gulf Coast.

\section{INTRODUCTION}

\section{GEOGRAPHY}

The assessment area considered in this report covers about $330,000 \mathrm{~km}^{2}\left(125,000 \mathrm{mi}^{2}\right)$ in the northeastern part of Mexico. The area includes the Burgos basin (primarily a Tertiary gas province), including its offshore part to the 1,000-m depth; the Sabinas basin where recent Mesozoic gas discoveries have been made; the adjacent Sierra Madre frontal basins (Parras and Magiscatzin basins); and the northern part of the Sierra Madre Oriental fold and thrust belt (fig. 1). Topography of the area is characterized by the flat-lying Gulf of Mexico coastal plain, the plateau regions along the Rio Grande and in western Coahuila State, the isolated ranges or sierras of central Nuevo Leon and eastern Coahuila (basins and ranges provinces of Humphrey, 1956), the rugged mountain belt along the front of the Sierra Madre Oriental, and the northern part of the Central Mesa region south of the Sierra Madre front.

The climate is semiarid to arid in most of the region. Annual precipitation is about 25 to $50 \mathrm{~cm}(10-20$ inches) in most parts of Coahuila State and part of Nuevo Leon State and about 50 to $75 \mathrm{~cm}$ (20-30 inches) in the coastal plain region of Tamaulipas State. In the high sierras south of Monterrey, precipitation may be to 100 $\mathrm{cm}$ (40 inches) or more in places.

\section{INFORMATION SOURCES}

Data and information used in preparing this report were compiled primarily from Mexican journals and other publications on petroleum geology and general geology of the area. Of particular value were publications by Lopez-Ramos (1980), Charleston (1974, 1981), Humphrey (1956), Smith (1970, 1971, 1981), Gonzales Garcia (1979), Wilson and Pialli (1977), McBride and others (1974), articles from the Oil and Gas Journal and World Oil, and the information files of Petroconsultants, S.A. Additional references are 


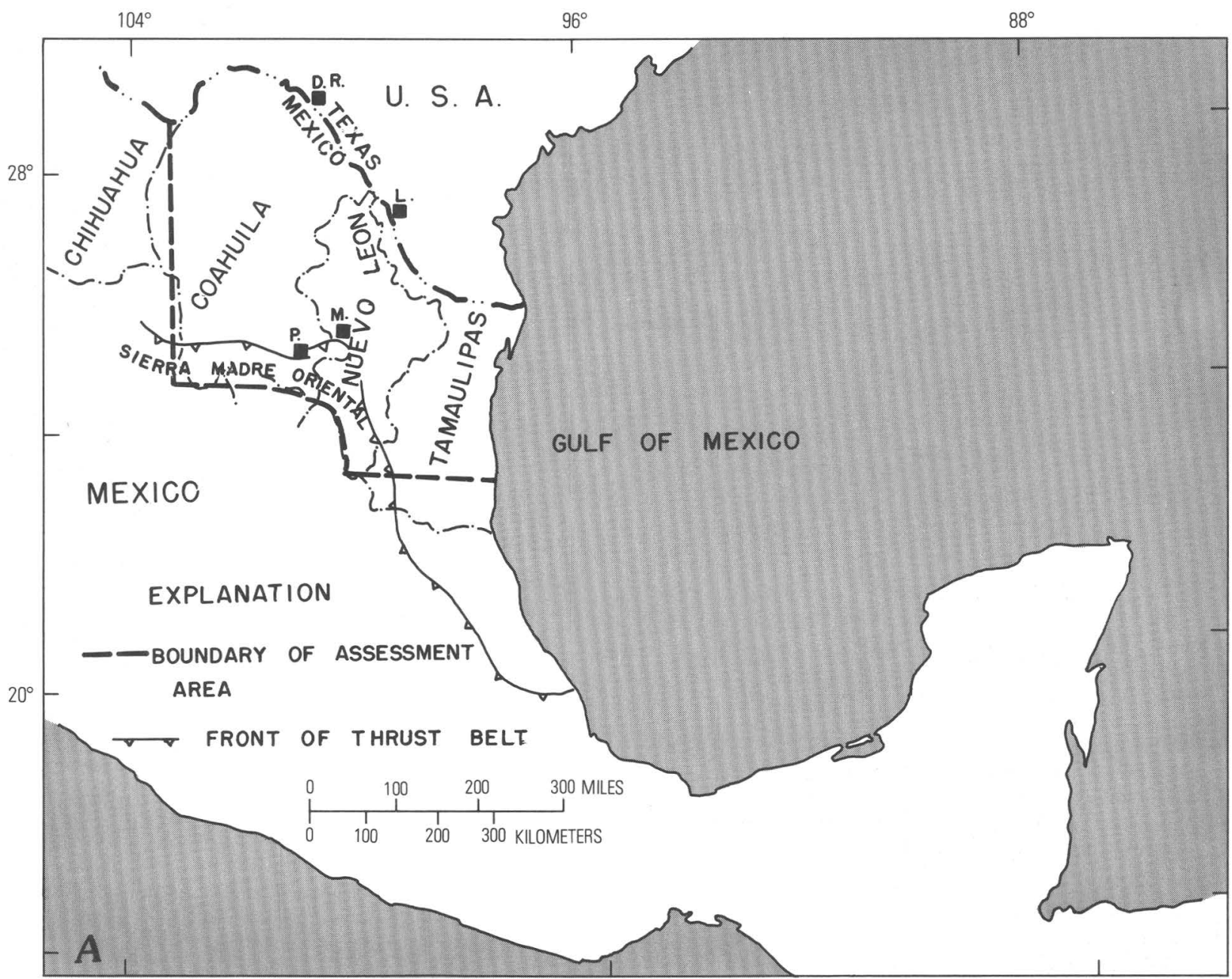

Figure 1.-Index maps of northeastern Mexico; cities shown are D.R., Del Rio, Texas; L, Laredo; M,

listed in the bibliography. Work on the report was completed in June 1981. Geological and other data made available after that date are not incorporated in the study.

The nomenclature used in the Texas area in this report was summarized from many reports; some has been adopted by the U.S. Geological Survey and some has not.

\section{ACKNOWLEDGMENTS}

This report benefited from constructive reviews and discussions by R. L. Miller, K. C. Bayer, J. W. Clarke, and C. D. Masters, U.S. Geological Survey. The resource assessment was prepared in collaboration with the Resource Appraisal Group of the Branch of Oil and Gas Resources, U.S. Geological Survey.

\section{REGIONAL GEOLOGY}

STRUCTURE

The main basin areas of northeastern Mexico are the Burgos basin, which is part of the Rio Grande embayment of the western Gulf of Mexico basin; the Sabinas basin (or "Gulf of Sabinas"); the Magiscatzin or Linares basin; and the Parras and La Popa basins (figs. 1-4). The Burgos basin occupies the eastern part of the assessment area and is filled with a thick sequence of Tertiary clastic rocks, which wedge-out rapidly updip to the west in the vicinity of Reynosa. West of the Tertiary wedge-out, the sedimentary cover comprises mainly Cretaceous marine carbonate rocks, which make up most of the surface exposures in Coahuila and Nuevo Leon, and a relatively unknown thickness of marine 


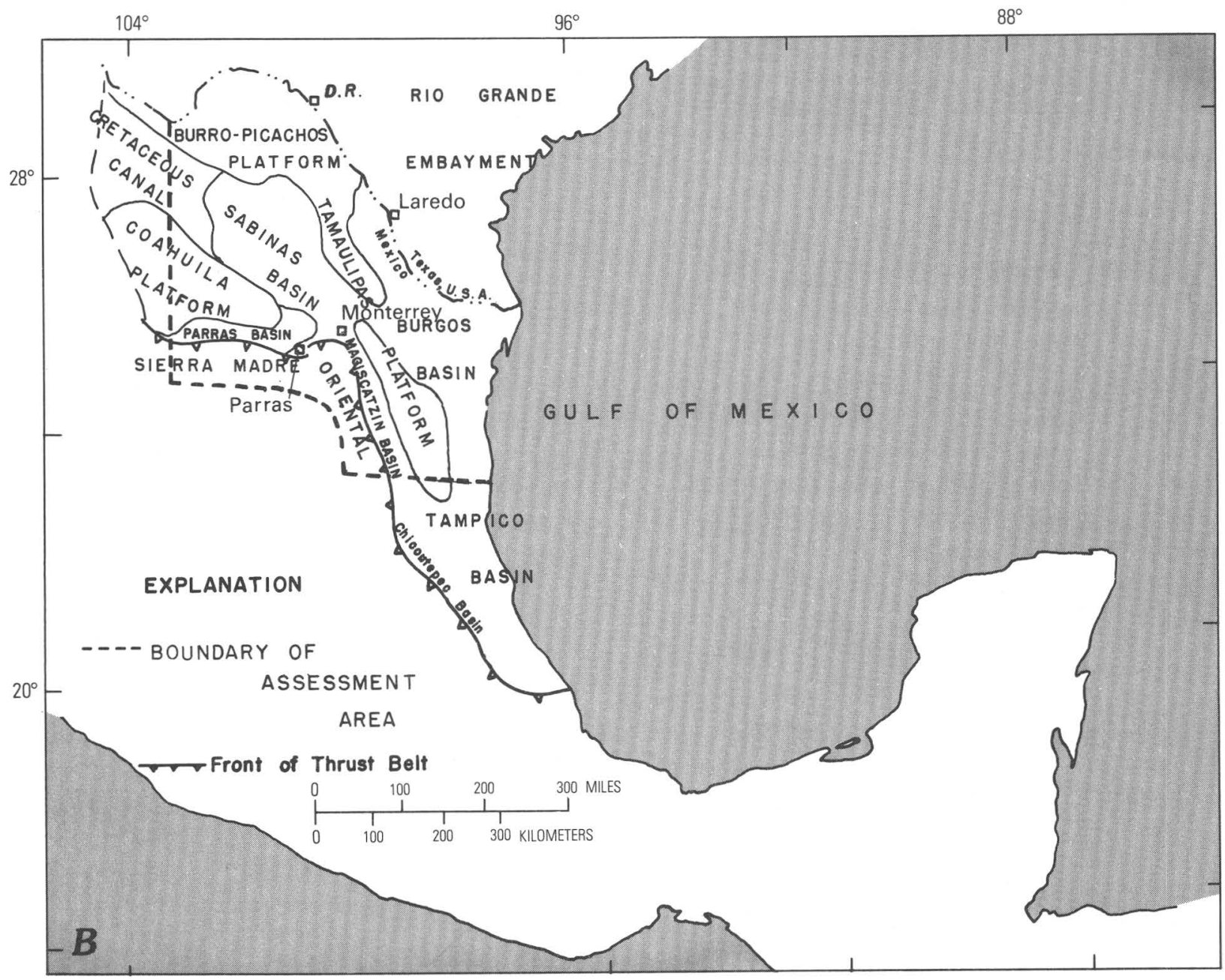

Monterrey, Mexico; P, Parras, Mexico. A, Political boundaries and assessment area; $B$, Main basins and uplifts.

Jurassic carbonate, clastic, and evaporite rocks (fig. 2, cols. 1-3). The Burgos basin is bounded on the west by the Tamaulipas platform (arch) and the southeastern extension of the Burro-Picachos platform. The Sabinas basin or "Gulf of Sabinas" lies west of this platform belt and merges with the Parras and La Popa basins around the southeast extension of the Coahuila platform. The broad Coahuila platform or "peninsula" forms the southern and western boundaries of the Sabinas basin and the north boundary of the Parras basin. The Parras basin occupies a relatively narrow west-east-trending tightly folded outcrop belt north of the Sierra Madre thrust and fold belt and merges on the east with the Magiscatzin (Linares) basin southeast of Monterrey. Together, these two basins form a relatively narrow, Late Cretaceous-Tertiary foredeep trough adjacent to the Sierra Madre Oriental, which is a broad belt of thick tightly folded and thrust-faulted Cretaceous and Jurassic platform carbonate deposits. To the south, the Magiscatzin basin joins the Tampico basin and the Chicontepec basin (fig. 1B).

Early growth of the Tamaulipas, Burro Picachos, and Coahuila platforms occurred in Triassic and Early Jurassic time as part of the regional tensional stresses associated with initial development of the ancestral Gulf of Mexico province. At this time, redbed clastics and evaporites were deposited in the Sabinas Gulf (ancestral Sabinas basin) and parts of the ancestral Gulf of Mexico basin (figs. 5-7). Intense growth of these paleostructures diminished after Triassic time, but moderate growth continued through most of the remainder of Mesozoic time and influenced depositional processes and distribution of both clastic and carbonate sedimentary facies. Growth of salt structures probably began 


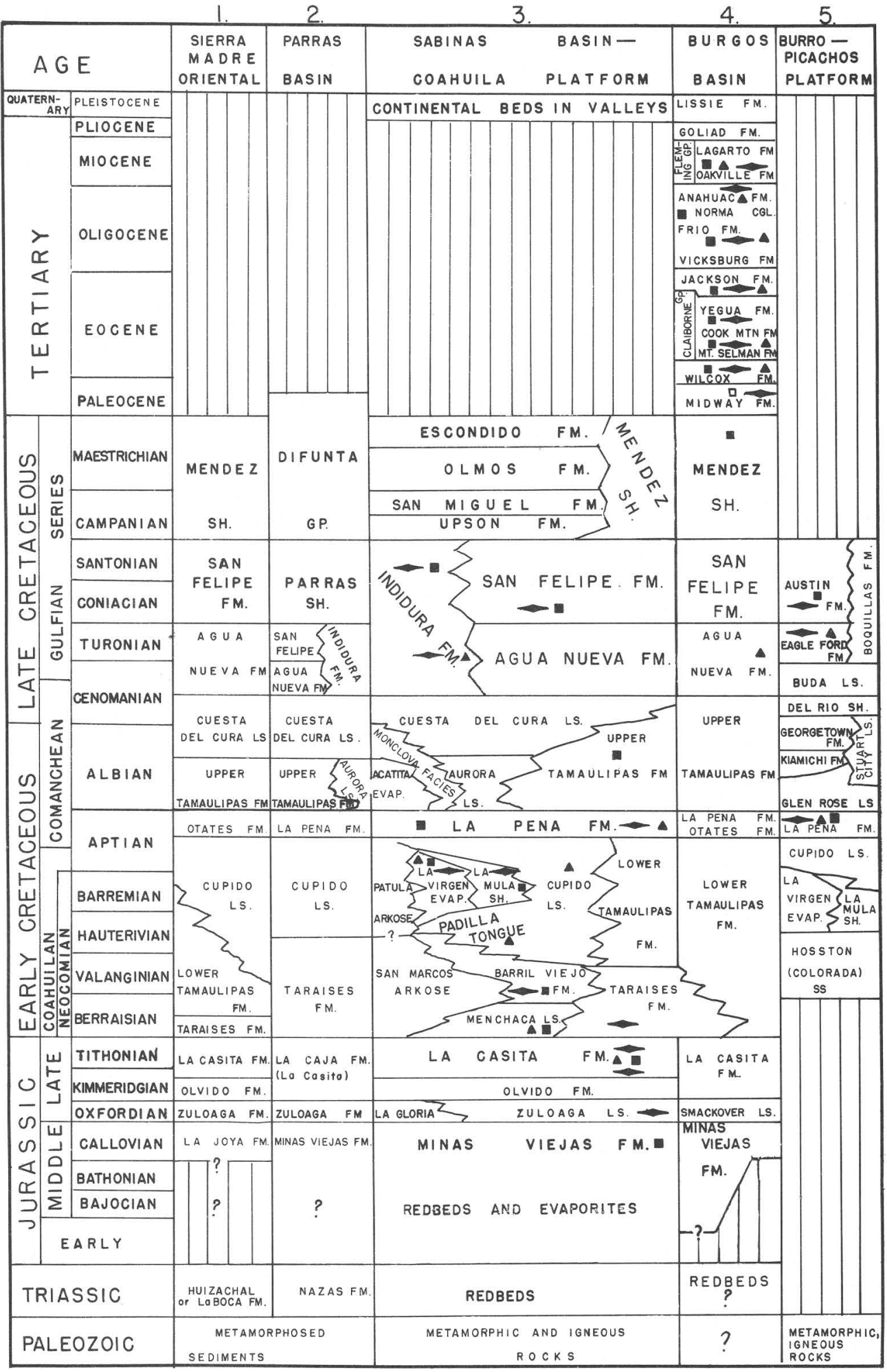

- OIL PRODUCTION GAS PRODUCTION SOURCE ROCK DEGIONAL SEAL

Figure 2.—Correlation chart, northeastern Mexico and adjacent area. 1., after Lopez-Ramos, 1980, Wilson and Pialli, 1977; 2., after Lopez-Ramos, 1980, McBride and others, 1974; 3., after Smith, C. I., 1981, Lopez-Ramos, 1980, Wilson and Pialli, 1977, Charleston, 1974; 4., after Lopez-Ramos, 1980; 5., after Smith, C. I., 1981, Lopez-Ramos, 1980, Gonzalez Garcia, 1979. 


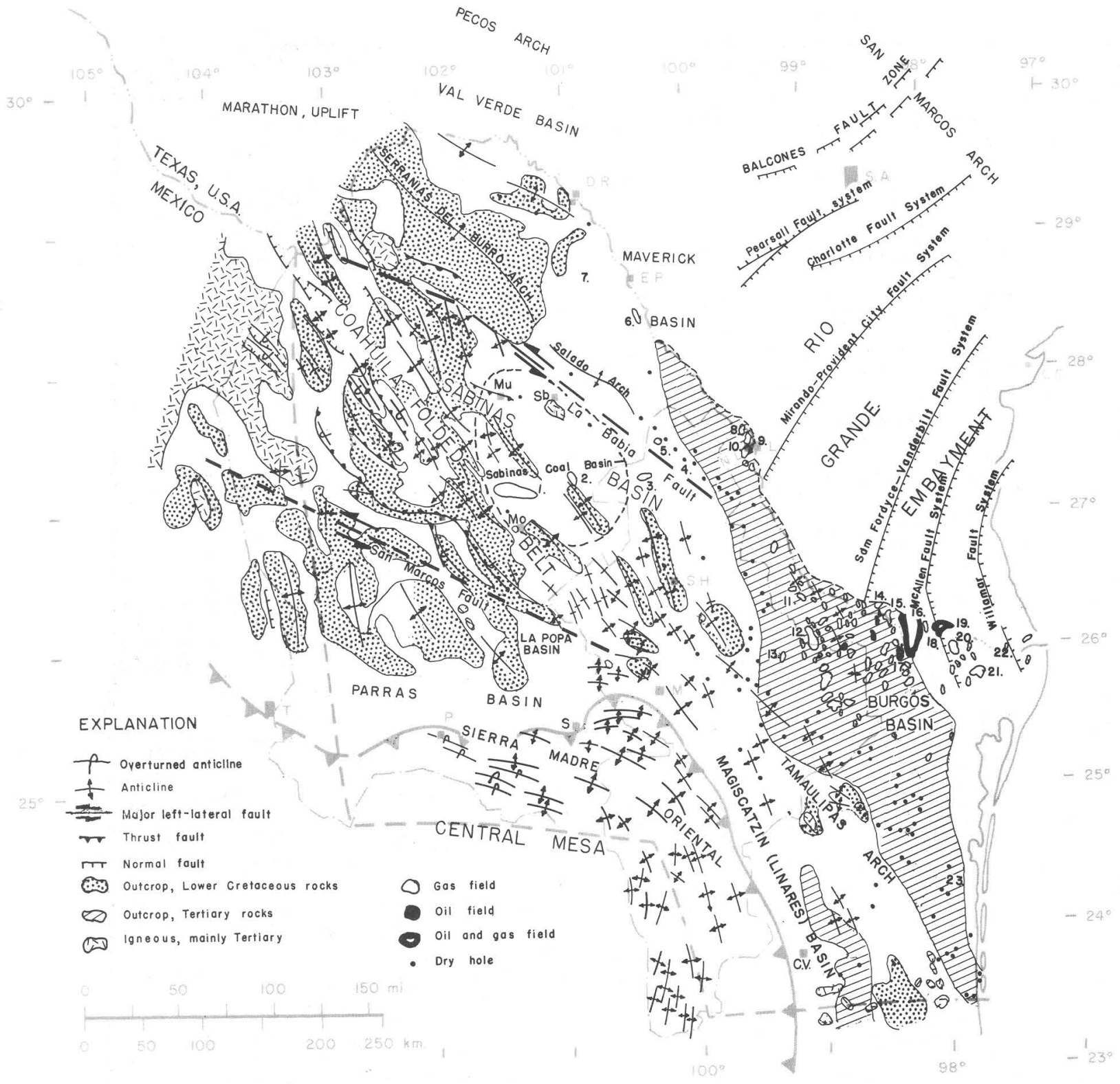

- assessment area

LIST OF NUMBERED FIELDS AND WELLS

$\begin{array}{ll}\text { 1. Buena Suerte-Monclova } & \text { 9. Laredo } \\ \text { 2. Ulua } & \text { 10. Oasis } \\ \text { 3. Lampazos } & \text { 11. La Presa } \\ \text { 4. Anahuac } & \text { 12. Culebra } \\ \text { 5. Garza } & \text { 13. Panalva } \\ \text { 6. Polvorin } & \text { 14. Mision } \\ \text { 7. Tribolites } & \text { 15. Comitas } \\ \text { 8. Totonaca } & \text { 16. Reynosa }\end{array}$

17. Monterrey

18. Francisco Cano

19. Trevino

20. Brasil

21. 18 de Marzo

22. Matamoras

23. Lerna

FIGURE 3.-Map of northeastern Mexico showing main structural features, oil and gas fields, important dry holes, and outcrop areas of Lower Cretaceous and Tertiary sedimentary rocks and Tertiary igneous rocks. Outcropping rocks are not shown in Sierra Madre Oriental in which mainly Cretaceous and some Jurassic rocks are exposed in fold and thrust structures. Lines of cross sections of figures 5, 6, and 7 are shown. Data are primarily from Charleston (1974, 1981), Lopez-Ramos (1980), and Corpus Christi Geological Society $(1978,1979)$. Significant fields or discoveries are numbered. Cities shown in Mexico: C, Chihuahua; C.V., Ciudad Victoria; Mo, Monclova; Mu, Muzquiz; N.L., Nuevo Laredo; P, Parras; S, Saltillo; Sb, Sabinas; S.H., Sabinas Hidalgo; T, Torreon; cities shown in Texas: C.C., Corpus Christi; D.R., Del Rio; E.P., Eagle Pass; L, Laredo; S.A., San Antonio. 


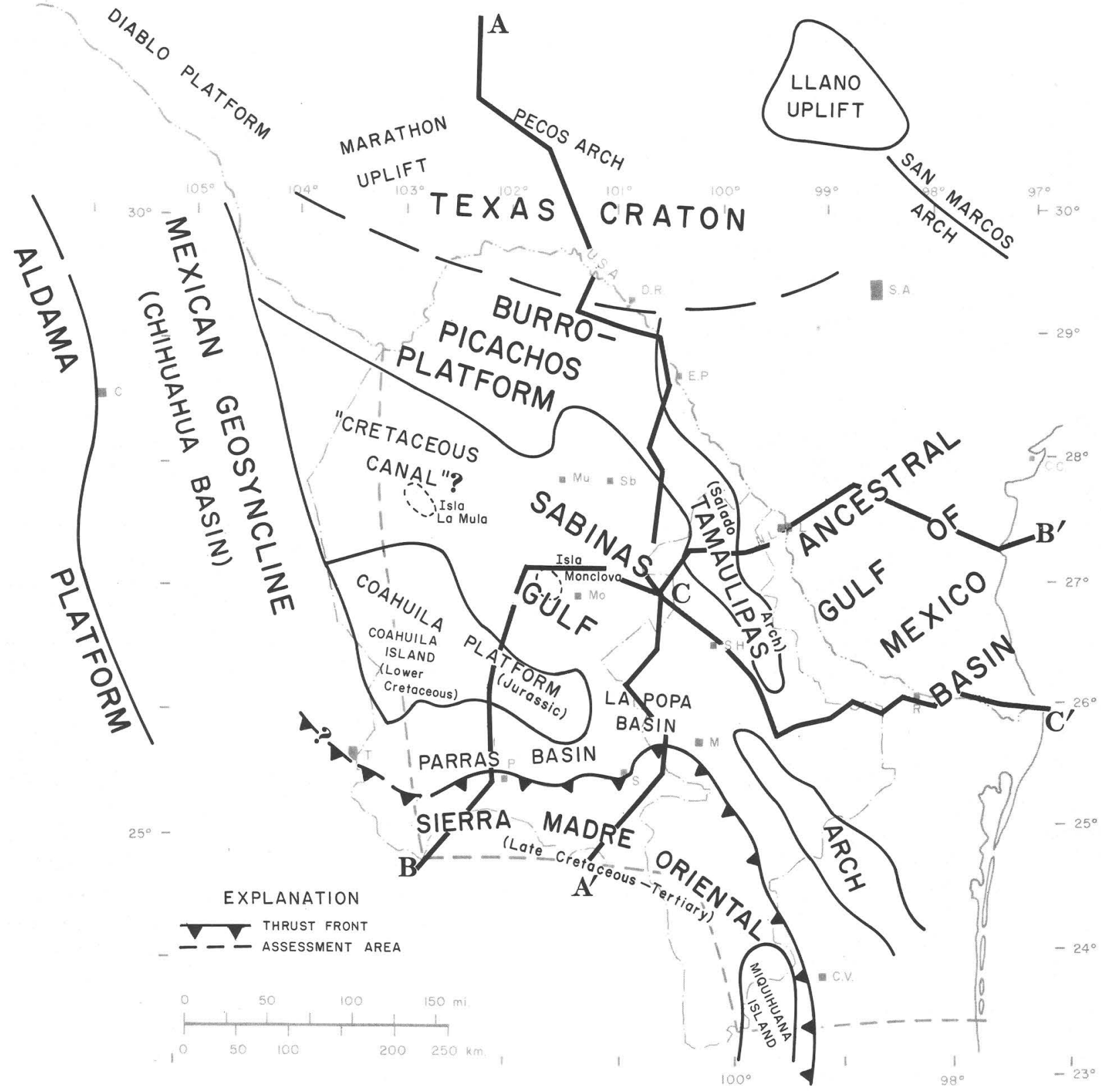

FIGURE 4.-Mesozoic paleostructure map showing regional basin and uplift features active during Jurassic and Cretaceous deposition. Lines of cross sections of figures 5, 6, and 7 are shown. Cities shown in Mexico: C, Chihuahua; C.C., Cuatro Cienegas; C.V., Ciudad Victoria; M, Monterrey; Mo, Monclova; Mu, Musquiz; N.L., Nuevo Laredo; P, Parras; R, Reynosa; S, Saltillo; Sb, Sabinas; S.H., Sabinas Hidalgo; T, Torreon; cities shown in Texas: D.R., Del Rio; E.P., Eagle Pass; L, Laredo; S.A., San Antonio. Sources of data: Humphrey (1956), McBride and others (1974), Gonzalez Garcia (1979), Lopez-Ramos (1980), Charleston (1974, 1981), and Smith, C. I. (1971, 1981).

by Late Cretaceous time and continued into early Tertiary time. Regional uplift during middle and late Tertiary time resulted in widespread erosion and exposure of Mesozoic rocks throughout most of northeastern Mexico, except for the Burgos basin, which underwent rapid subsidence throughout Tertiary time.

The Burgos structural basin is a part of the Rio Grande embayment, which forms the western part of the Gulf of Mexico basin. The basin area contains a thick sequence of Tertiary and upper Mesozoic deposits, which are cut by a series of normal fault zones displaced downward on the Gulf Coast side and roughly parallel to the coastline (fig. 3). Most of these are growth faults active during Tertiary deposition. Numerous faulted anticlinal or domal folds are present, some of which may be related to deep-seated salt structures. 


\section{A}

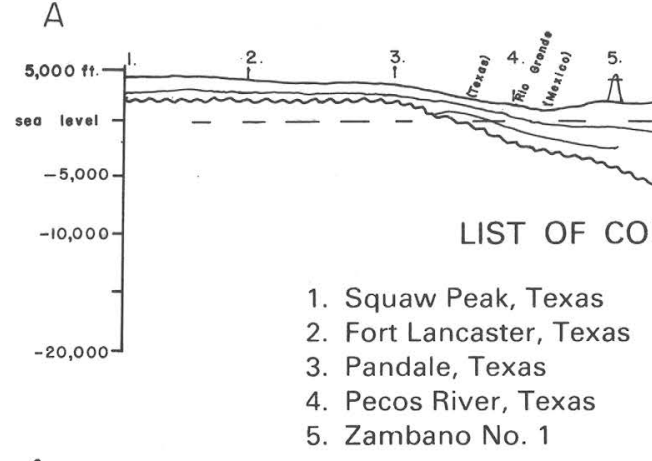

C

A

5. Zambano No. 1

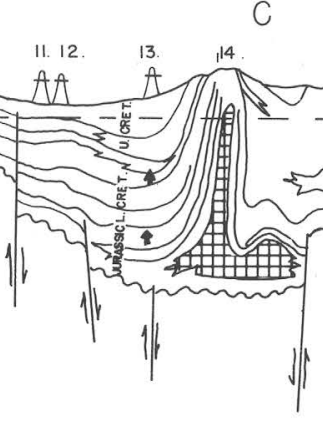

6. Trevino No. 1

7. Chupadero No. 1

8. Tribolites No. 1

9. Peyotes No. 2-A

10. Lomerio de Peyotes

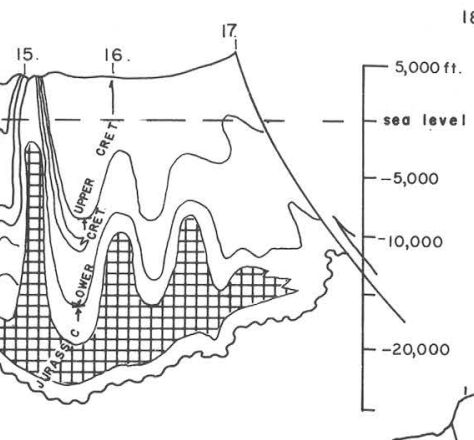

A

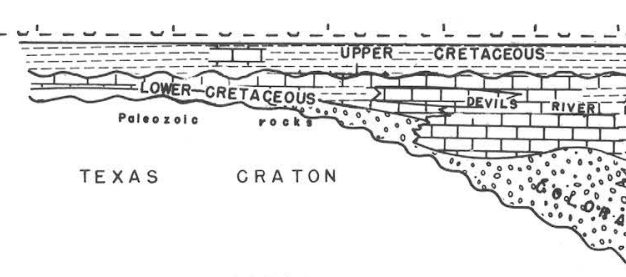

EXPLANATION

MAIN LITHOLOGIC FACIES

5:800 conglomerate

Sandstone

$\because \because \because$ Arkosic sondstone or conglomerate

簿满溥 Redbeds

Marine shale, gray/black

Limestone

Dolomite

i․․ Anhydrite or gypsum

世纽 sait

B

\begin{tabular}{|c|c|c|c|}
\hline Gas production & $\AA$ & Well & \\
\hline Oil production & 3. & Surfoce & section \\
\hline
\end{tabular}

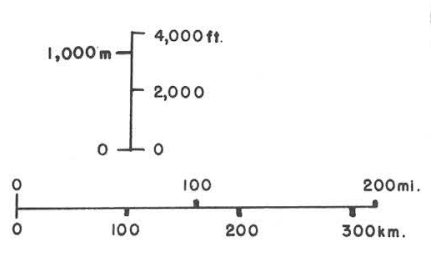

11. Silencio No. 1

12. Gato No. 1

13. Ulua No. 1

14. Sierra Laja

15. Sierra La Gava

16. Paredon

17. Saltillo

18. Sierra de Sombreratilio
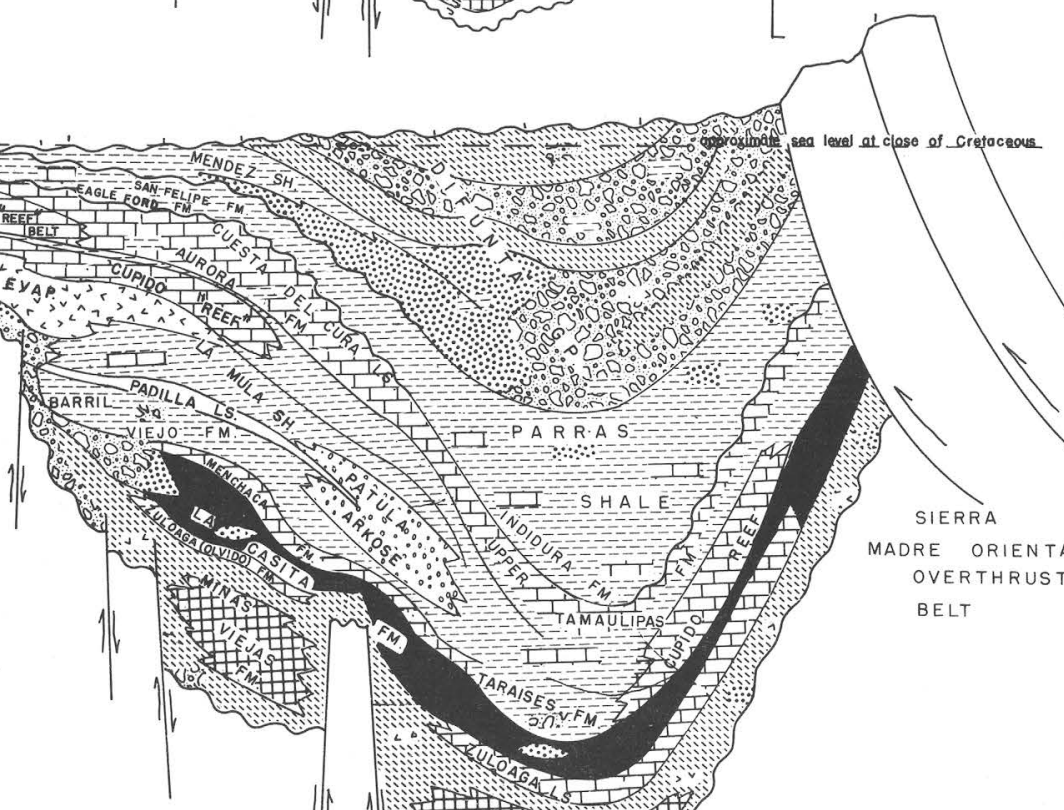

FId

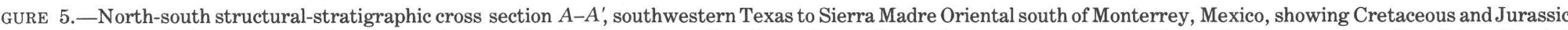
sedimentary facies, structural features, and productive intervals. Top of La Casita Formation is the top of the Jurassic. Datum for lower cross section $B$ is estimated sea level at close of Cretaceous time; datum for upper cross section $A$ is present-day sea level. Cross section is based on available published data and is partly schematic, particularly in older and deeper parts of section. Data are mainly from Humphrey (1956), Charleston (1974, 1981), Smith, C. I. (1970, 1971, 1981), Lopez-Ramos (1980), and Gonzalez Garcia (1979). Line of cross section $A-A^{\prime}$ is shown on figures 8-11. 
19. Sierras de Simon and Ramirez 20. Sierra de Parras

21. Sierra de Los Alamitos

22. Sierra de San Marcos

B

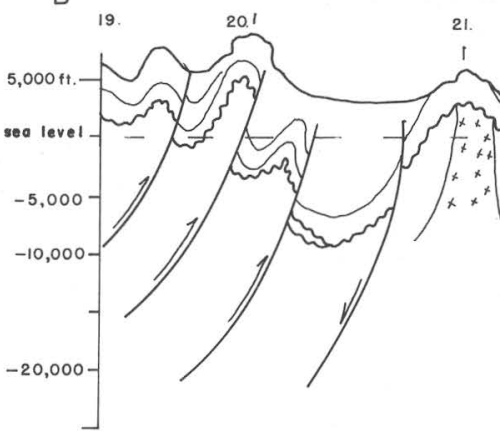

B
23. Sierra de Barril Viejo

24. Potrero de Menchaca

25. Buena Surete No. 1

26. Monclova No. 1
27. Lampazas No. 1

28. Reforma No. 1

29. Anahuac Field

30. Ambrosia No. 1
31. Laredo Field

32. Humble No. 1 Benavides, Texas

33. Philips, Nueches No. 1, Texas

34. Continental, No. 16 Driscoll, Texas

C
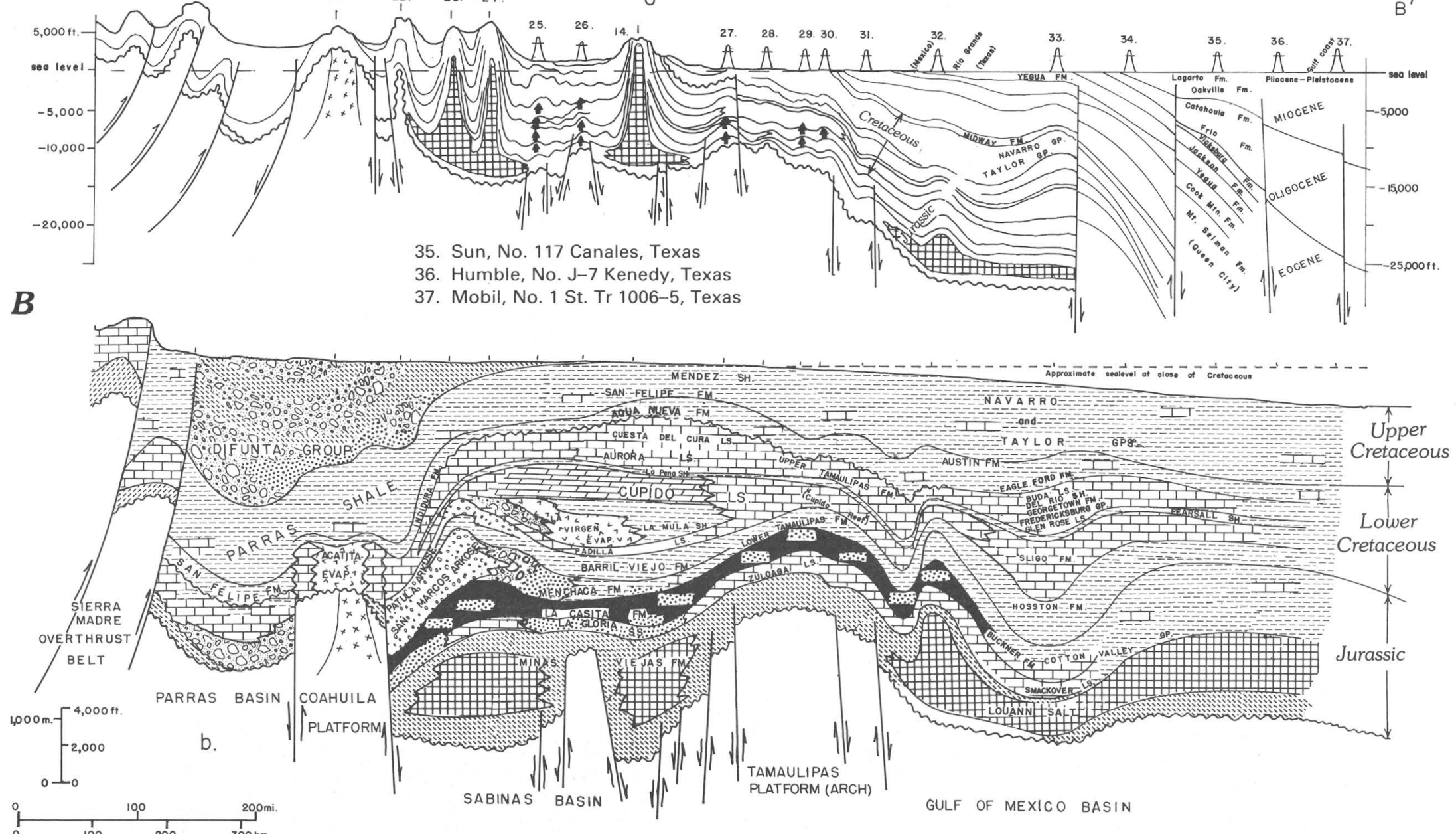

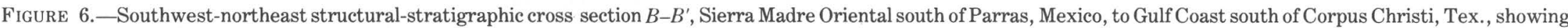
Cretaceous and Jurassic sedimentary facies, structural features, and productive intervals. Datum for lower cross section $B$ is estimated sea level at close of Cretaceous time; datum for upper cross section $A$ is present-day sea level. Cross section is based on available published data and is partly schematic, particularly in older and deeper parts of section. Sources of data are same as for figure 5 . Lithologic explanation is on figure 5 . Line of cross section $B-B^{\prime}$ is shown on figures $8-12$. 
C

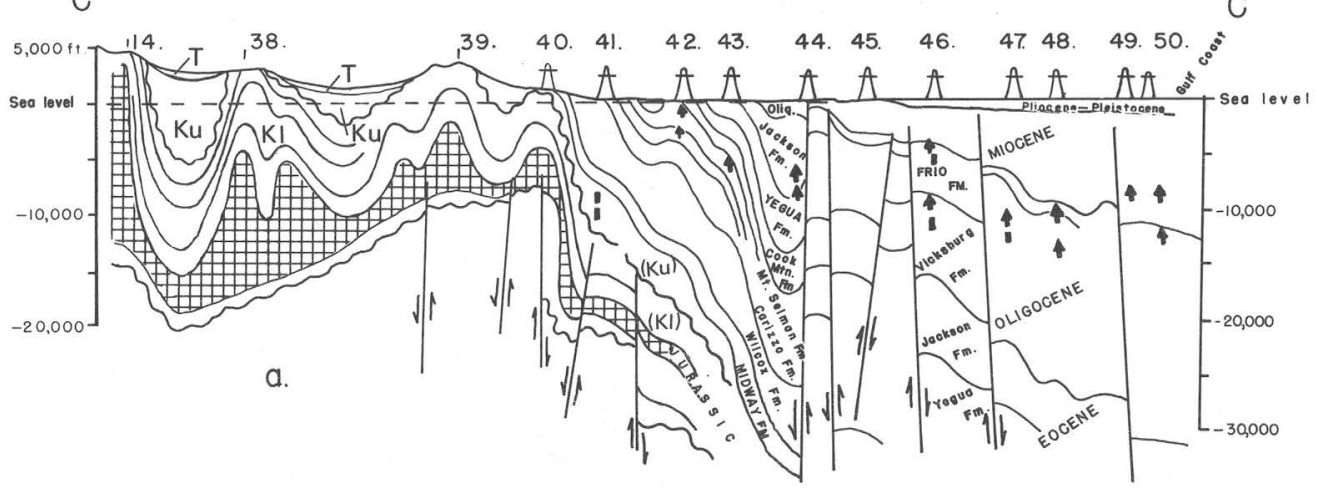

LIST OF CONTROL POINTS
14. Sierra Laja
38. Sierra Sabinas
39. Sierra de Picachos
40. Los Ramones No. 1
41. Los Herreras No. 1
42. Santa Monica No. 1
43. El Pato No. 1
44. Zacate No. 101
45. El Charro No. 1
46. Reynosa No. 1
47. Trevino No. 1
48. Cardenas No. 1
49. Texas No. C-1
50. Santa Fe No. 1

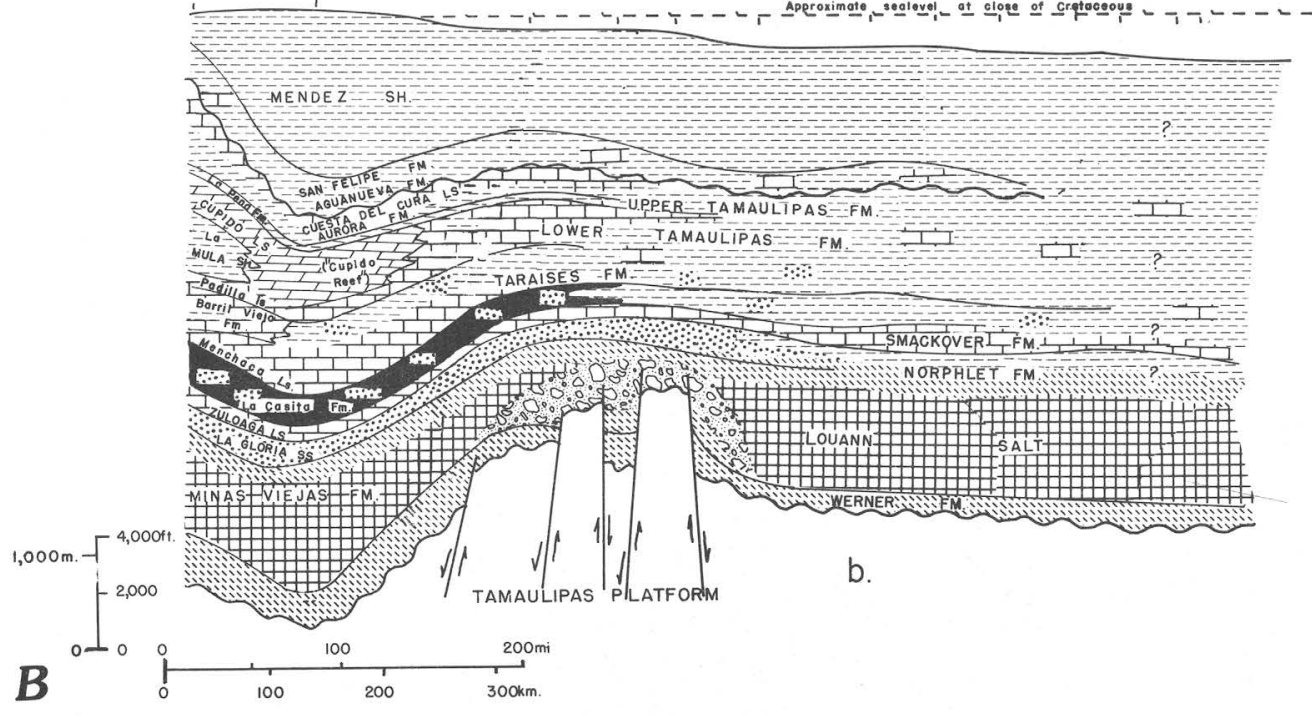

FigURE 7.-West-east structural-stratigraphic cross section $C-C^{\prime}$, Sabinas basin to Gulf Coast at mouth of Rio Grande, showing Cretaceous and Jurassic sedimentary facies, structural features, and productive intervals. Datum for lower cross section $B$ is estimated sea level at close of Cretaceous time; datum for upper cross section $A$ is present-day sea level. Cross section is based on available published data and is partly schematic, particularly in older and deeper parts of section. Sources of data are same as for figure 5. Lithologic explanation is shown on figure 5 . Line of cross section $C-C^{\prime}$ is shown on figures 8-12. 
The Tamaulipas and Burro-Picachos platforms are broad and relatively gentle uplifts with superimposed north- or northwest-trending anticlines (fig. 3) that may have formed as a result of northeast-directed compressive Laramide stresses during the development of the Sierra Madre thrust and fold belt (Humphrey, 1956; Charleston, 1974).

The Sabinas basin is an elongate northwest-oriented basin with numerous northwest-trending local uplifts or sierras of exposed Cretaceous rocks (fig. 3), some of which have a narrow elongate belt of exposed Jurassic rocks in their centers (figs. 5-7). In the northern part of the basin, local uplifts are primarily elongated, relatively narrow, asymmetric anticlines, some of which are overturned and faulted (fig. 3). In the central and southern part of the basin, the folds are similar but tend to be broader to domal in shape with sharply plunging axes. These structures may be related in part to movement of underlying Jurassic salt and(or) gypsum (Weidie and Martinez, 1972; Gonzalez Garcia, 1979). Lower Cretaceous rocks are exposed in the centers of several larger structures, and in a few cases Upper Jurassic rocks are exposed (figs. 3, 5, 6, 7).

The Parras and La Popa basins (figs. 1, 3, 4) are characterized by surface exposures of thick Upper Cretaceous clastic sedimentary rocks and east-west oriented elongate anticlines that become more tightly folded and thrust faulted to the south toward the Sierra Madre Oriental thrust belt (Weidie and Murray, 1967; McBride and others, 1974). The small La Popa basin lies between the Sabinas basin on the north and the Parras basin on the south, but in many respects it is simply an extension of the Sabinas basin. Structures in the La Popa basin are similar to those of the Sabinas and are elongated northwest-southeast. The Parras is a narrow east-west basin lying between the Coahuila platform on the north and the Sierra Madre fold and thrust belt on the south, although thrusts related to the Sierra Madre belt extend into the younger rocks of the Parras basin. Structures in the northeastern part of the Parras basin are broad, domal folds or open, elongate folds, with minor thrust faults displaced toward the north. In the main part of the basin nearer the Sierra Madre front, folds are highly elongated east-west, tight, overturned, and thrusted toward the south, dipping away from the main Sierra Madre mass (Krutak, 1965; McBride and others, 1974).

\section{STRATIGRAPHY}

INTRODUCTION

The sedimentary cover of northeastern Mexico consists primarily of Mesozoic rocks in the States of Coa- huila and western Nuevo Leon (Sabinas basin and adjacent area) (fig. 2). Mesozoic sedimentary rocks are 1,550 to $6,000 \mathrm{~m}(5,000-20,000 \mathrm{ft})$ thick in the Sabinas basin (fig. 6) and up to more than $9,000 \mathrm{~m}$ $(30,000 \mathrm{ft})$ thick in the Parras and La Popa basins (figs. 5, 6, 8, 9, 10, 11). On the Burro-Picachos and Coahuila platforms and in the Sierra Madre thrust belt, Mesozoic rocks are about 1,550 to $4,650 \mathrm{~m}$ (5,000-15,000 ft) thick, except where partly removed by erosion in the main uplift areas. Except for a thin Paleocene section in the Parras and Magiscatzin basins, Tertiary rocks are present only in the Burgos basin, where they range in thickness from about 1,550 to $3,000 \mathrm{~m}(5,000-10,000 \mathrm{ft})$ in the outcrop belt on the west side of the basin to more than $15,500 \mathrm{~m}(50,000$ $\mathrm{ft}$ ) near the Gulf Coast (fig. 12). Total thickness of the sedimentary cover in the deeper part of the Burgos basin is not known but probably ranges to more than $21,000 \mathrm{~m}(70,000 \mathrm{ft})$ of Tertiary and Mesozoic rocks.

\section{BASEMENT}

The oldest rocks exposed in the area are scattered exposures of upper Paleozoic metamorphosed sedimentary rocks in the Burro-Picachos and Coahuila platform areas. Little is known of the basement rocks in the basins. According to Gonzalez Garcia (1979), the basement is probably composed of Permian-Triassic metasedimentary and intrusive rocks, but some areas of unmetamorphosed upper Paleozoic sedimentary rocks may be present in downfaulted blocks of the basement.

\section{TRIASSIC}

Unmetamorphosed rocks of Triassic age are known to overlie the basement in a few places around the borders of the assessment area, but little is known of their character except that they are primarily redbeds where observed, and they may underlie much of the area. South of Monterrey in the Linares trough, 2,000 $m$ or more of Triassic redbeds (La Boca Formation) are present in exposures on the flanks of the Tamaulipas platform.

\section{JURASSIC}

The Jurassic Sabinas basin or Gulf of Sabinas was bordered by the ancestral Burro-Picachos and Tamaulipas platforms on the north and east and the Coahuila platform on the west. The ancestral basin opened on the southeast into the Tampico basin and on the east, through an opening between the Tamaulipas and Burro-Picachos platforms, into the ancestral Gulf of Mexico basin (figs. $1 B, 3,4$ ). The Jurassic sequence in 


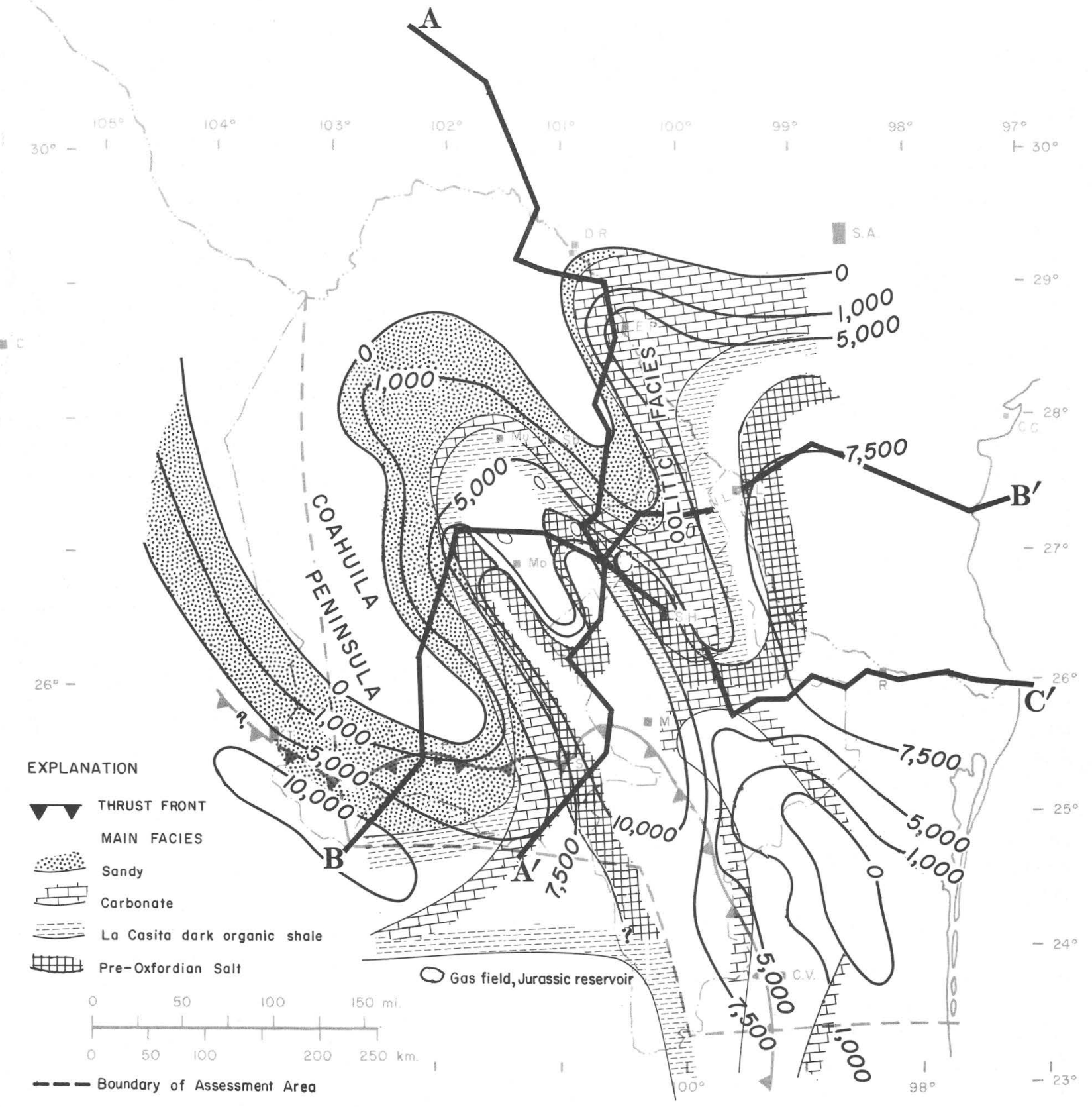

Figure 8.-Approximate thickness in feet, partly restored, Jurassic System, showing approximate distribution of pre-Oxfordian salt, postsalt Upper Jurassic main sedimentary facies, and gas fields producing from Upper Jurassic reservoirs. Lines of cross sections of figures 5, 6, and 7 are shown. Sources of data: Humphrey (1956), Erben (1957), Weidie and Wolleben (1969), Gonzalez Garcia (1979), Lopez-Ramos (1980), and Newkirk (1971).

northeastern Mexico consists of, in ascending order, the Minas Viejas (and its equivalent, the La Joya), the Zuloaga (and its equivalent, the La Gloria), and the Olvido and La Casita Formations (fig. 2). The Minas Viejas is a thick unit of redbeds, gypsum or anhydrite, and salt with minor interbeds of shale, carbonate, and sandstone. These beds are exposed in the centers of several diapiric anticlines in the southeastern part of the Sabinas basin and have been penetrated in several wells. The formation may be approximately equivalent in age to the Louann Salt and the Werner Formation of the western Gulf of Mexico basin. Exact distribution and thickness of the salt section is not known, but original depositional thickness may have been as much 


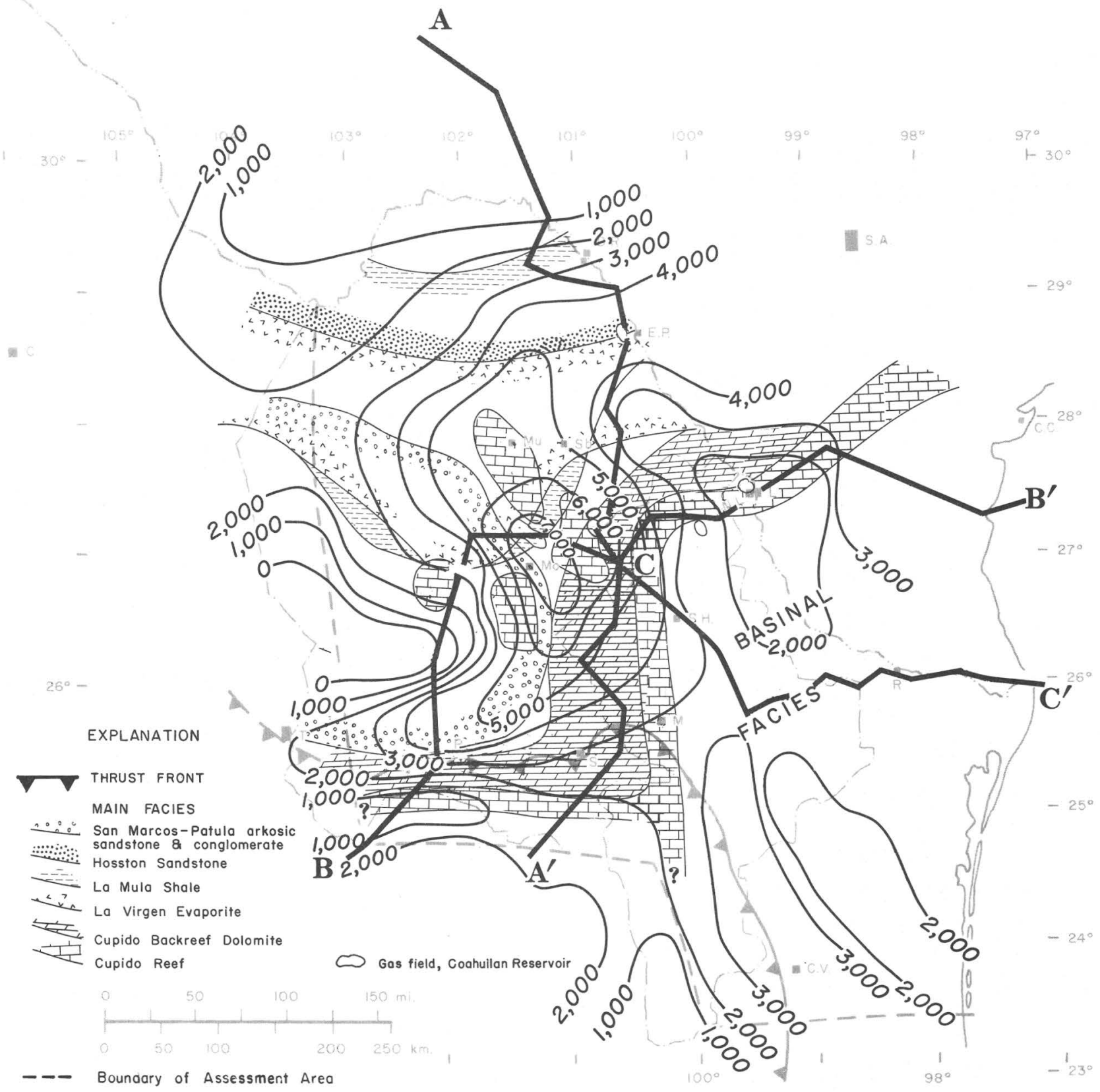

Figure 9.-Approximate thickness in feet, partly restored, Coahuilan Series, Lower Cretaceous, showing main sedimentary facies and gas fields producing from rocks of Coahuilan Series. Lines of cross sections of figures 5, 6, and 7 are shown. Sources of data: Humphrey (1956), Krutak (1965), Smith, C. I. (1971, 1981), Charleston (1974, 1981), Gonzalez Garcia (1979), Wilson and Pialli (1979), Lopez-Ramos (1980), Bebout (1977), Scott and Kidson(1977), and Rainwater (1971).

as $1,550 \mathrm{~m}(5,000 \mathrm{ft})$ or more in the southeastern part of the Sabinas basin. The Minas Viejas probably grades to redbeds of the La Joya Formation around the periphery of the salt basin; it is absent on the Coahuila platform (figs. 5-6).

The Zuloaga Limestone is a fossiliferous and oolitic limestone unit of middle to late Oxfordian age (fig. 2).
It is equivalent to the Smackover and Norphlet Formations of the U.S. Gulf Coast area (Imlay, 1980) and is widely distributed in northeastern Mexico (figs. 5-7). The Zuloaga has been identified in surface exposures in several breached anticlines in the Sabinas basin and in outcrops in the Sierra Madre Oriental fold and fault belt south of Monterrey. The Zuloaga grades westward 


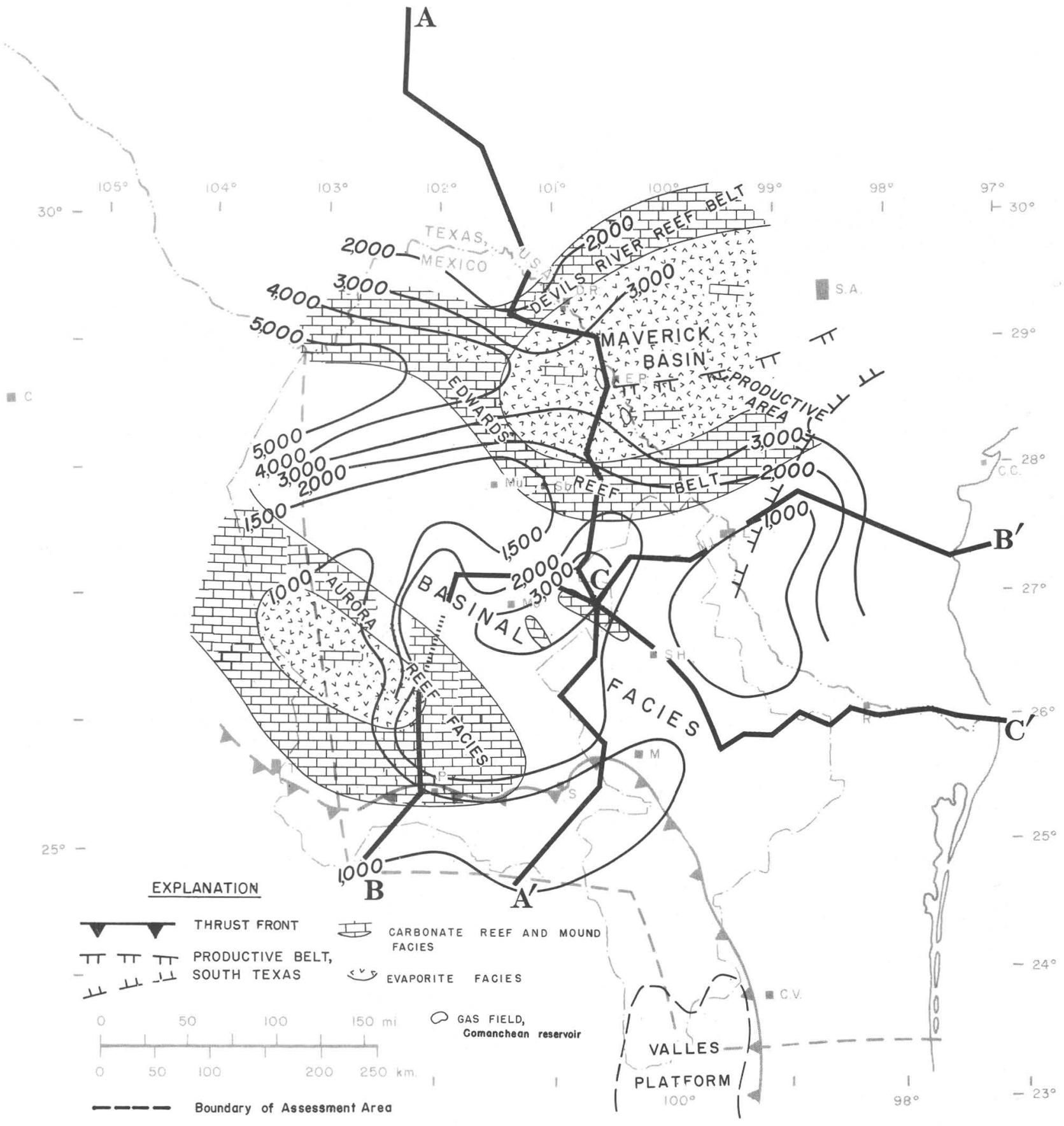

FIGURE 10.-Approximate thickness in feet, partly restored, Comanchean Series, showing main sedimentary facies and gas fields producing from rocks of Comanchean Series. Lines of cross sections of figures 5, 6, and 7 are shown. Sources of data: Humphrey (1956), Gonzalez Garcia (1979), Lopez-Ramos (1980), Rainwater (1971), and Fisher and Rodda (1969).

into sandstone and conglomerate of the La Gloria Sandstone, which is composed of lithologies reworked from underlying beds during the transgressive advance of the Upper Jurassic seaway. A limy transitional facies assigned to the Olvido Formation may be present between the Zuloaga or La Gloria and the overlying La Casita Formation.
The La Casita Formation is Kimmeridgian and Tithonian in age, equivalent to the Cotton Valley Group (Schuler and Bossier Formations) and to the Buckner Formation of the U.S. Gulf Coast (Imlay, 1980). The unit is about 300 to $1,000 \mathrm{~m}(975-3,250 \mathrm{ft})$ thick and is mostly black carbonaceous shale, marl, siltstone, and minor limestone in the lower part grading up to sand- 


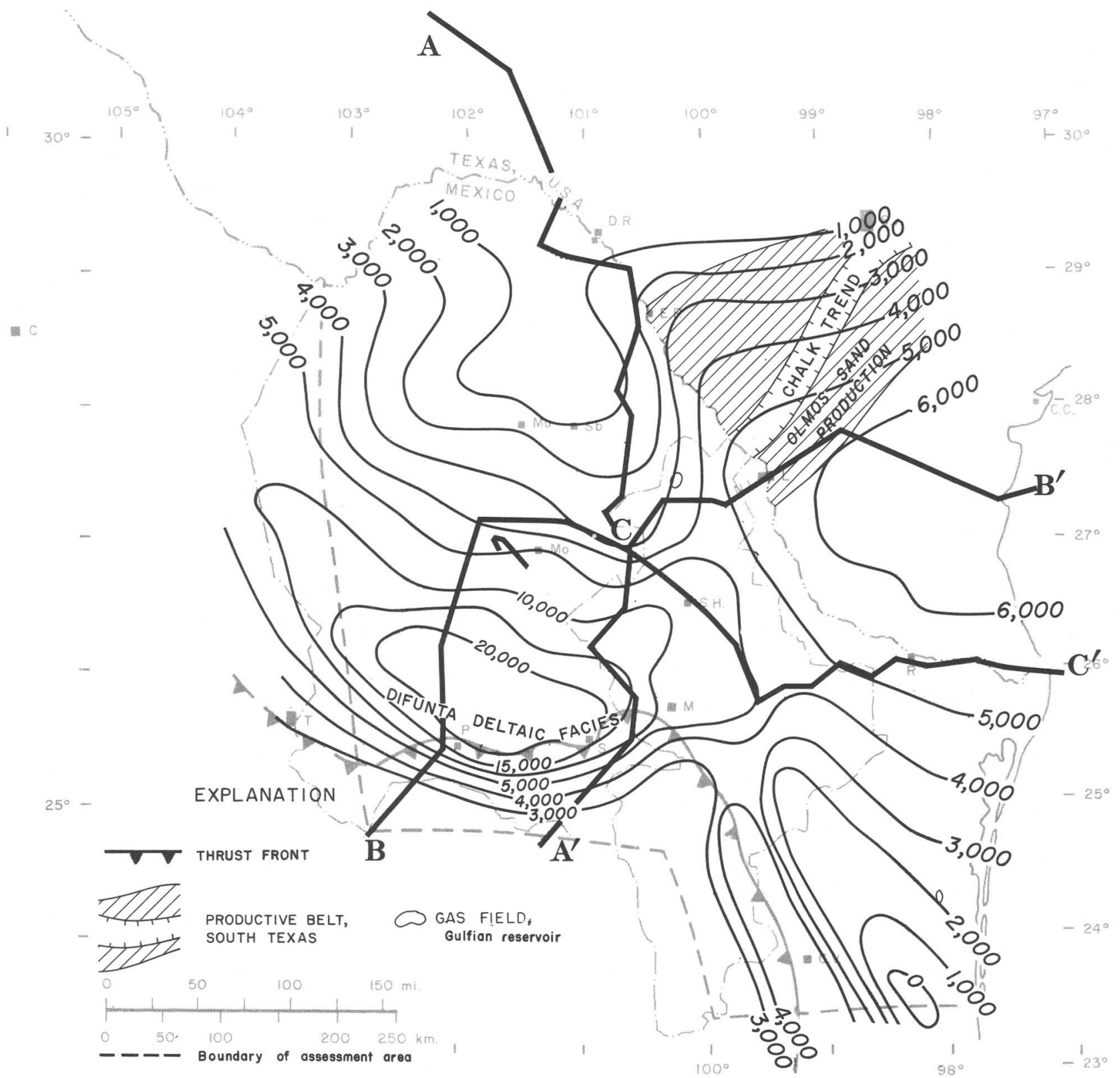

FIGURE 11.-Approximate thickness in feet, partly restored, Gulfian Series, showing main sedimentary facies and gas and oil fields producing from rocks of Gulfian Series. Lines of cross sections of figures 5, 6, and 7 are shown. Sources of data: Humphrey (1956), McBride and others (1974), Gonzalez Garcia (1979), Lopez-Ramos (1980), Holcomb (1971).

stone with some conglomerate and limestone in the upper part. The La Casita Formation occupies the main part of the Sabinas and Parras basins and extends southward into the Sierra Madre Oriental and Tampico basin areas where it becomes a more limy facies than in the Burgos basin (figs. 1, 8). In the vicinity of the Coahuila platform, the unit becomes much more sandy and in places is conglomeratic (fig. 6). In the Sabinas basin, the contact between the La Casita and the overlying Lower Cretaceous beds is transitional.

\section{LOWER CRETACEOUS}

Lower Cretaceous deposition in northeastern Mexico and adjacent Texas is dominated by two main marine transgressive cycles of reef-bearing carbonate facies deposition, the Cupido and Sligo Formations of Coahuilan age and the Glen Rose and Edwards or the Aurora and Cuesta del Cura Limestones of Comanchean age (figs. 2, 9, 10). The overlying Upper Cretaceous sequence is dominated by marine and continental clastic 


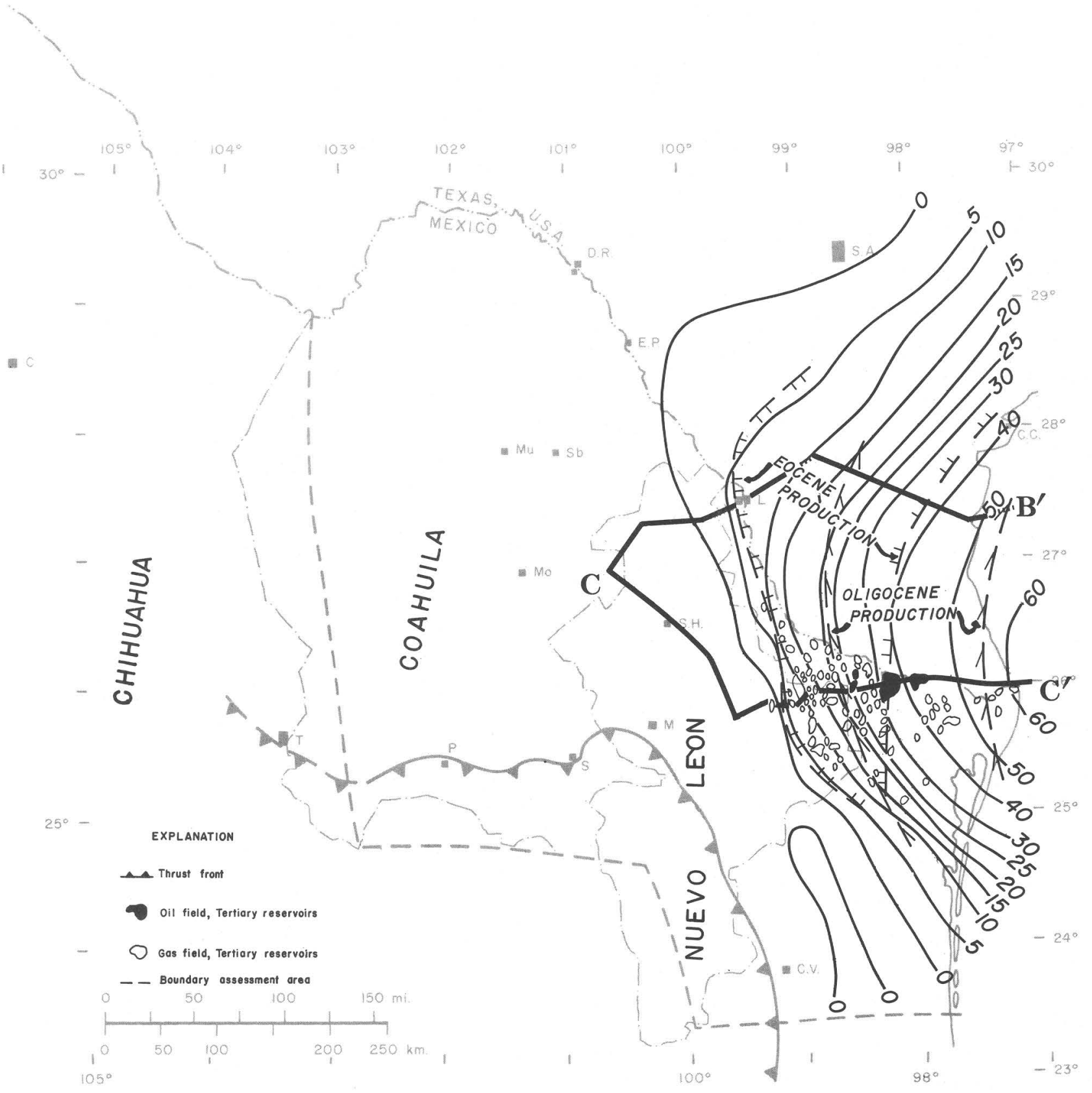

FIGURE 12.-Approximate thickness in thousands of feet, Tertiary System, showing gas and oil fields producing from Tertiary rocks in Mexico and from productive trends in south Texas. Sources of data: Guzman and others (1955), Beebe (1968), Fisher and MeGowen (1967), Lofton and Adams (1971), Shinn (1971), Tipsword and others (1971), and Lopez-Ramos (1980).

deposits of Gulfian age that include substantial thicknesses of deltaic deposits and some coal beds in the upper half (figs. 2, 11).

Lower Coahuilan (lower Neocomian) lowermost Cretaceous deposits are dark shale and shaly limestones of the Taraises and Menchaca Formations, which are conformable with the underlying La Casita Formation. The Taraises and Menchaca were deposited in the main area of the Sabinas basin and part of the Parras basin.
These formations grade laterally into the lower part of the San Marcos Arkose near the Coahuila platform and into the Colorado Sandstone (equivalent to the Hosston Formation of Texas) near the Burro-Picachos platform (figs. 2, 5, 6, 9). In the vicinity of Monterrey in the southeastern part of the Sabinas basin, the upper part of the Taraises grades into the lower part of the Cupido Limestone, which may represent the initial depositional stages of the Cupido-Sligo platform margin reef belt. 
To the south and east, equivalents of the Taraises are in the lower part of the Tamaulipas Formation, which is a deeper water offshore or basinal shaly carbonate and shale.

Middle Coahuilan beds in the central and southeastern part of the Sabinas basin are represented by the marine shales and marls of the Barril Viejo Formation, which grade upward into the fossiliferous rudist-bearing limestone and dolomite beds of the Padilla Tongue (Sacramento Limestone of Charleston, 1974), a westward-extending tongue of the Cupido platform limestone facies. The upper part of the Padilla contains oolitic and bioclastic beds in places. Along the southwestern flank of the basin, adjacent to the Coahuila platform, these beds grade into the green and red shales of the lower La Mula Shale, which grades farther southwest into part of the San Marcos and Patula Arkoses. To the east, Barril Viejo and Padilla grade into the main facies belt of the lower Cupido Limestone, which extends in a broad north-south belt along the east side of the Sabinas basin (figs. 5, 6, 9).

Upper Coahuilan beds in the main Sabinas basin area are represented by the limy and shaly shell-fragment beds of the upper La Mula Shale and the gypsum or anhydrite and limy or dolomitic beds of the La Virgen Evaporite. These beds grade southwestward into the Patula Arkose and eastward into the middle part of the Cupido Limestone. The La Mula and La Virgen Formations apparently represent a back-bank facies of the Cupido platform margin carbonate buildup. In Barremian time, organic bank and reef beds of the middle Cupido were deposited along a southwest-northeast belt between Saltillo in Coahuila State, and Laredo, Tex., across western Nuevo Leon State (fig. 9). This facies continues eastward into Texas as the Sligo Formation. In Nuevo Leon State, Cupido bank margin beds grade eastward to lime mudstone and shale of the lower Tamaulipas basinal facies. Lower Aptian (upper part of the Coahuilan Series) beds represent progradation and maximum development of the Cupido platform carbonate facies, which at this time covered most of the western part of Nuevo Leon and central to eastern Coahuila. The main platform margin Cupido-Sligo reef facies developed at this time and extended across Nuevo Leon between Laredo, Tex., and Monterrey. From here, the trend of the bank margin facies is uncertain, but it apparently continues southward for a short distance and then may continue westward into the Sierra Madre Oriental fold and thrust belt south of Saltillo (Gonzalez Garcia, 1979; Smith, 1981; Conklin and Moore, 1977; Wilson and Pialli, 1977).

Lower Comanchean shale and siltstone beds of the widespread upper Aptian La Pena Formation overlie the Cupido Limestone throughout the Sabinas basin and adjacent area (figs. 5-7). These beds, which are

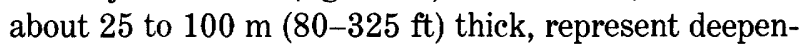
ing and transgression of the Cretaceous seas and termination of Cupido carbonate platform deposition and related organic bank and reef growth. At this time, widespread deposition of dark open-shelf shale, marl, and nodular limestone occurred across the submerged platform. To the east and southeast, the La Pena grades to open marine basinal thin-bedded argillaceous and cherty limestone and shale of the Otates Formation. The La Pena beds apparently represent the early stages of major transgression and foundering of the Cupido platform by basinal deposits of lime mudstone (upper Tamaulipas Formation) as the Cretaceous seas deepened and platform carbonate deposition shifted toward shallow-water areas to the west in the vicinity of the partly submerged Coahuila platform and to the north in the general area of the submerged BurroPicachos platform (figs. 4, 10). The Sabinas basin formed an embayment (Ocampo embayment) where the shaly facies of the upper Tamaulipas and the lime mudstone facies of the Aurora were deposited farther to the west at this time. These beds grade laterally into rudist banks and reefs of the Aurora Limestone deposited in shallow-water environments in the vicinity of the Burro-Picachos platform (equivalent to the Glen Rose Limestone, a shelf deposit) (Smith, 1981).

Late Comanchean time was marked by submergence and transgression of the Cupido platform during early Albian time and the beginning of the second main Cretaceous carbonate cycle or reef belts, which included the Glen Rose, Edwards, Stuart City, and Devils River Limestones (figs. 5, 6, 10). Reef and organic bank facies growth continued in the vicinity of the submerged Coahuila platform and along the south border of the Texas craton from where the bank margin expanded and prograded basinward, with the total complex forming the successively deposited Glen Rose and lower Aurora Limestone, followed by the Stuart City, Devils River, and middle Aurora organic carbonate units, and finally in late Albian time, by the upper Aurora and upper Devils River bank carbonate units (figs. 6, 10). Farther south, in the Tampico basin area, the El Abra Limestone and equivalent reef and bank margin facies, and in southeastern Mexico, the main reef and bank margin facies of the Sierra Madre Limestone, were deposited in late Albian time.

\section{UPPER CRETACEOUS}

Following deposition of the Aurora Limestone and upper part of the Tamaulipas Formations and equivalent beds, marly beds of late Albian age were deposited across much of the Sabinas basin or Cupido platform 
area (Georgetown Limestone of the Washita Group and Kiamichi Formation of the Fredericksburg Group and Sue Peaks or Sombreratillo Marl of Smith, 1981). Along a broad belt between Laredo and Monterrey, these beds grade upward into the Cuesta del Cura Limestone, a sequence of thin-bedded, cherty limestones, which were deposited approximately along the trend of the previously deposited Cupido bank margin facies. The Cuesta de Cura beds are partly equivalent to the Del Rio Clay and Buda Limestone of southwestern Texas and northern Coahuila.

Deposition of the Cuesta del Cura and equivalents was followed by an influx of fine calcareous clastics and argillaceous carbonates of the Cenomanian or basal Upper Cretaceous Agua Nueva or Indidura Formations, which probably represent the initial clastic influx related to Larmide orogenic activity (Smith, 1981). Organic carbonate production was greatly diminished at this time as terrigenous clay and silt covered the entire platform province.

The Parras Shale is a thick $(1,000-2,000 \mathrm{~m}$; $3,250-6,500 \mathrm{ft})$ sequence of dark-gray marine shale and siltstone overlying the limy Indidura beds. The Parras becomes more sandy in the upper part and is present throughout much of the Sabinas, Parras, and La Popa basins (figs. 5-6). Eastward, toward the Gulf basin, these beds grade into the lower part of the Mendez Shale (fig. 6), which is deeply buried beneath the Gulf Coastal Plain.

The Difunta Group conformably overlies the Parras or Mendez Shale and occupies most of the Parras, La Popa, and southern part of the Sabinas basins, except where removed by late Cenozoic erosion in the main uplift areas. The Difunta is a group of seven formations, which are thickest in the Parras and La Popa basins where they are 3,000 to $5,000 \mathrm{~m}(9,750-16,000$ $\mathrm{ft}$ ) or more thick, and is also present in the southern part of the Sabinas basin (figs. 5-6). This sedimentary complex represents the accumulation of a series of prograding and retrograding deltas into the Upper Cretaceous and Paleocene Gulf seaway by terrigenous detritus from highland areas in the vicinity of and southwest of the Sierra Madre Oriental and the Coahuila platform. Deltaic, nearshore, and marine-shelf environments are recognized in this complex intertonguing of sandstone, siltstone, redbeds, marine gray shale, and minor limestones deposited in the strongly subsided Parras and La Popa basins. The main part of the Difunta Group is of latest Cretaceous (CampanianMaestrichtian) age, but the upper part is probably Paleocene (McBride and others, 1974). Eastward, these beds grade to the upper part of the Mendez Shale in the Gulf Coastal Plain region. The Difunta is partly removed by late Cenozoic erosion in the main uplift areas of the Sabinas basin and is absent within and south of the Sierra Madre Oriental, which was rising at this time.

\section{TERTIARY}

Except for probable Paleocene rocks in the uppermost beds of the Difunta Group, Tertiary rocks in northeastern Mexico are present only in the Burgos basin, which lies east of the trend of the Mesozoic Tamaulipas platform (fig. 12). West of here, Tertiary rocks are absent by erosion or nondeposition. The Burgos basin contains an eastward-thickening and offlapping wedge of Cenozoic open marine and nearshore marine, deltaic, and continental deposits 1,550 to

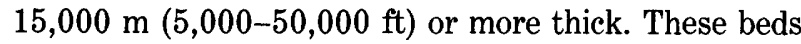
are of Paleocene through Holocene age and are continuous with similar sequences of the western Gulf basin in Texas. However, some of the Tertiary formation names whose type localities are in Texas are no longer used in Texas even though they are valid in Mexico.

Paleocene rocks (lower part of Midway Formation of Mexico, lower part of Midway Group of Texas) crop out in a narrow belt along the western border of the Burgos basin, and a thin section of Paleocene beds also crops out in the Linares or Magiscatzin basin southeast of Monterrey. In the Burgos basin subsurface, these beds comprise a lower sequence of marine sandstone and glauconitic sandstone and shale grading upward to primarily marine shale in the upper part. The beds thicken eastward and are probably about 600 to $1,550 \mathrm{~m}$ $(2,000-5,000 \mathrm{ft})$ thick near the Gulf coastline, where they are at depths greater than $12,000 \mathrm{~m}(40,000 \mathrm{ft})$.

Eocene rocks crop out along the western border of the Burgos basin but are in part overlapped by Pleistocene and younger beds. Eocene rocks are primarily a marine sandstone and shale sequence of six main formations, thickening eastward to more than $6,150 \mathrm{~m}$ $(20,000 \mathrm{ft})$ near the Gulf Coast. The lithologic framework of subsurface Eocene rocks was worked out by industry geologists and others from the extensive drilling activity in the U.S. Gulf Coast area. Most of these lithologic divisions are also recognized in the Burgos basin of Mexico (fig. 2). All of the units thicken rapidly eastward from the outcrop belts along the west side of the basin.

The Wilcox Group is the basal Eocene unit and consists of alternating beds of marine shale and sandstone with some lignitic beds near the center. The Wilcox is about 770 to $1,230 \mathrm{~m}(2,500-4,000 \mathrm{ft})$ thick and is overlain by the Claiborne Group, which in ascending order consists in the Burgos basin of the Mount Selman, Cook Mountain, and Yegua Formations, all of which thicken eastward in the subsurface. 
The Carrizo Formation, which conformably overlies the Wilcox, is a unit of fine- to medium-grained nearshore marine sandstone and shale, which thins and disappears southward in the Burgos basin.

The Mount Selman Formation (a term no longer used in Texas) is primarily marine and nearshore sandstone and shale 310 to $1,230 \mathrm{~m}(1,000-4,000 \mathrm{ft})$ thick. A deltaic unit (Queen City Sand) north of the embayment is an important reservoir section in south Texas.

The Cook Mountain Formation (a term used in the Burgos basin and in Texas north of the Rio Grande embayment) is a marine glauconitic sandstone and gray shale unit, which is probably several thousand feet thick in the deep subsurface to the east.

The Yegua Formation is a marine and nearshore marine or continental carbonaceous sandstone and shale unit 110 to $1,100 \mathrm{~m}(350-3,500 \mathrm{ft})$ thick.

The Eocene Jackson Group in Texas or Jackson Formation in the Burgos basin conformably overlies the Yegua Formation of the Claiborne Group and is a sequence of marine sandstone and sandy shale about 310 to $2,000 \mathrm{~m}(1,000-6,500 \mathrm{ft})$ thick.

Oligocene rocks thicken from about $310 \mathrm{~m}(1,000 \mathrm{ft})$ in the outcrop area on the west to more than $6,100 \mathrm{~m}$ $(20,000 \mathrm{ft})$ in the eastern Burgos basin subsurface and represent continental beds on the west grading to nearshore marine and basin deposits to the east. A narrow band of outcropping Oligocene rocks extends from just west of Reynosa southeastward to near the Gulf Coast east of Ciudad Victoria (figs. 3, 11).

The Vicksburg Formation of earliest Oligocene age is mainly marine shale in the Burgos basin subsurface with beds of volcanic ash and some nearshore sandstone units in the western area. Vicksburg beds are about $3,000 \mathrm{~m}(9,750 \mathrm{ft})$ thick in the Reynosa Oriente No. 1 well and are thicker eastward toward the Gulf basin.

The Oligocene Frio Formation, which overlies the Vicksburg, is primarily a relatively thin continental facies in outcrop sections in southwestern Texas and northeastern Mexico, but it thickens and changes rapidly to a thick sequence of nearshore marine sandstone and shale in the subsurface. The marine sandstone and shale facies of the Frio reaches maximum thickness, as much as $2,000 \mathrm{~m}(6,500 \mathrm{ft})$ in the subsurface, along a northwest-southeast belt passing east to Reynosa. East of there, the formation grades to a basinal shale sequence more than $3,000 \mathrm{~m}(9,750 \mathrm{ft})$ thick.

The Norma Conglomerate, which unconformably overlies the Frio in the Burgos basin to the west, is a 75

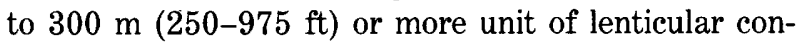
glomerate and sandstone deposited as a large alluvial fan. The unit grades basinward to marine sandstone and shale representing a regressive unit at the top of the Frio. The Norma represents coarse continental beds deposited during development of the regional mid-Oligocene unconformity.

The Anahuac Formation is an upper Oligocene subsurface unit of variable thickness (50-150 m; 160-485 $\mathrm{ft}$ ) overlying the Norma in southwestern Texas. It is a marine unit of foraminiferal shale and poorly consolidated sandstone that probably extends to the southwest into the Burgos basin subsurface.

Miocene rocks crop out in a relatively broad band lying east of the Oligocene outcrop belt. They are in part overlapped by Quaternary beds in the eastern part of the Burgos basin.

The Fleming Group of Mexico includes the Oakville and Lagarto Formations, and it unconformably overlies the Anahuac and equivalent beds, thickens rapidly eastward from less than $100 \mathrm{~m}(325 \mathrm{ft})$ in the outcrop area to $3,000 \mathrm{~m}(9,750 \mathrm{ft})$ or more in the subsurface near the Gulf Coast. In south Texas the Oakville and Lagarto are not assigned to a group, and the Fleming Formation is not used. These beds are primarily a continental and nearshore marine sandstone, conglomerate, and shale facies on the west and grade eastward to marine shale and sandstone toward the Gulf of Mexico.

Pliocene rocks comprise a sequence of about 10 to 35 $\mathrm{m}$ (33-110 ft) of outcropping continental sandstone, gravel, and clay beds assigned to the Goliad Sand along the eastern border of the Miocene outcrop belt. These beds thicken in the subsurface to as much as $200 \mathrm{~m}$ $(650 \mathrm{ft})$ or more near the Gulf Coast.

\section{QUATERNARY}

Continental gravels and clay overlie the Pliocene beds and onlap older Tertiary beds in a broad area extending from the Gulf Coast as far west as Reynosa. These beds thicken to more than $300 \mathrm{~m}(975 \mathrm{ft})$ near the mouth of the Rio Grande. Relatively thin deposits of Quaternary gravels are also present in topographically low areas throughout northeastern Mexico, particularly in the Sabinas basin, where they usually overlie Upper Cretaceous beds.

\section{PETROLEUM GEOLOGY}

\section{INTRODUCTION}

Exploration for petroleum in northeastern Mexico was stimulated during the 1920's and 1930's by the possibility of extending the producing zones of the Texas Gulf Coast southward into Mexico. Geophysical work, following surface geological studies in the upper Tertiary outcrop belt west and south of Reynosa, identified several subsurface structures, which resulted in 
early drilling activity and the discovery of a small accumulation of gas in Eocene lenticular sandstone at the La Presa field (fig. 3) west of Reynosa in 1931. During the period 1931 to 1937 , three other relatively small gas fields were discovered, all productive from Eocene sandstone reservoirs, including the Laredo field near Nuevo Laredo about $122 \mathrm{~km}$ (75 mi) northwest of the La Presa field. These discoveries, which demonstrated a significant potential for hydrocarbons in northeastern Mexico, led to additional seismic work in the coastal plain area south of the Rio Grande. Between 1945 and 1955, 21 additional gas fields with some oil production were discovered, including the largest (Reynosa, about 2 TCF) and the six other most important fields. The main production from these fields was from sandstone reservoirs in the Oligocene Frio Formation, which extended the Frio productive belt of Texas southward some distance into the Burgos basin of Mexico. A total of about 90 gas and gas-condensate fields and a few small oil fields has been found in the Burgos basin with cumulative production (about 1970) of approximately 4 TCF gas and $100 \mathrm{MMB}$ oil and condensate. Estimated total ultimate recoverable reserves from these fields is about 5 TCF gas and $400 \mathrm{MMB}$ oil and condensate.

An early period of petroleum exploration in the Sabinas basin, based on field geology, resulted in the drilling of two unsuccessful wells in the northwestern part of the basin. Further field work was conducted by Imlay $(1936,1940,1944,1953)$, Kellum and others (1936), Humphrey $(1949,1956)$, and by PEMEX (Petroleos Mexicanos) geologists between 1940 and 1960 . A geophysical and drilling program was then organized, which resulted in the drilling of two unsuccessful wildeats, Minas Viejas (1968) and Anhelo (1969), in the southeastern part of the basin. In 1976, gas was discovered in Jurassic and Cretaceous rocks in the northwestern part of the basin at the Buena Suerte No. 1 well (fig. 3). Since then, a total of at least 10 gas fields has been discovered producing from Cretaceous carbonate and Jurassic sandstone reservoirs, with many of the wells producing at high rates. A small discovery in Upper Cretaceous beds was made at Garza No. 1 well in 1957 on the eastern border of the basin about $75 \mathrm{~km}$ (45 mi) west of Nuevo Laredo (fig. 3).

\section{TERTIARY, BURGOS BASIN}

Gas and condensate production in the Burgos basin is from sandstone and siltstone reservoirs of the Frio, Anahuac, and Vicksburg Formations of Oligocene age and of the Mount Selman, Jackson, and Yegua Formations of Eocene age, and Wilcox Formation of Eocene and Paleocene age (fig. 2). Minor gas is also produced from Miocene sandstone reservoirs, and some oil is produced from Frio and Vicksburg reservoirs. Production occurs in relatively well defined belts extending into Mexico from productive trends in southwestern Texas, arranged generally from oldest (Eocene) on the west to youngest (Miocene or late Oligocene) on the east (fig. 12).

\section{RESERVOIRS}

Lower Miocene sandstone reservoirs are productive over a relatively wide area along the Gulf Coast in Louisiana and Texas. In southwestern Texas and northeastern Mexico, a few fields produce from these beds in the vicinity of the Rio Grande delta. The reservoir sands are mainly discontinuous deltaic and delta fringe sand bodies probably deposited by the ancestral Rio Grande delta.

The Oligocene reservoir section of the Vicksburg, Frio, and Anahuac Formations is thickest along a belt about $50 \mathrm{~km}(30 \mathrm{mi})$ wide between Reynosa and Matamoras extending southward into the Burgos basin. Approximately within this belt the main production occurs, with maximum production from the Frio sands. Reservoirs are discontinuous and lenticular deltaic fringe sandstone and siltstone bodies interbedded with marine and nonmarine shale beds. Some localized conglomeratic beds are present in the Frio, and overall the sandstone sequence tends to be more shaly and silty than equivalents in southwestern Texas. Reservoir quality in the Oligocene beds diminishes southward into the Burgos basin; permeability is generally reported as poor to medium; porosity is highly variable but ranges as high as 20-25 percent in some cases. Gross pay thickness ranges from less than $3 \mathrm{~m}(10 \mathrm{ft})$ to as much as 155 to $310 \mathrm{~m}(500-1,000 \mathrm{ft})$ in some cases. Production rates range from $1 \mathrm{MMCFD}$ or less to as much as 5 MMCFD or more in a few cases from Frio reservoirs. Cumulative production from Oligocene reservoirs as of about 1970 was somewhat over 2 TCF and about 30 MMB oil and condensate, almost all from Frio sandstone and siltstone reservoirs.

Eocene reservoirs in the Burgos basin include sandstone and siltstone beds of the Wilcox, Mount Selman, Yegua, and Jackson Formations, which produce gas and some condensate in about 60 fields. Total production, however, is much less than that from the Oligocene reservoirs. Nearshore marine and nonmarine discontinuous sandstone beds are gas reservoirs in the upper Eocene Jackson Formation at a few fields in the northwestern part of the Burgos basin, but production is relatively minor. The bulk of Eocene production is from deltaic and nearshore marine sandstone reservoirs of the Claiborne Group (Yegua, Cook Mountain, and 
Mount Selman Formations). These reservoirs are best developed within a belt between Laredo, Tex., and Reynosa, Mexico, extending across the Rio Grande southward into the Burgos basin. Basal Eocene reservoirs are deltaic, fringe, and barrier bar sandstones deposited during a major regressive cycle (Rainwater, 1967; Fisher and McGowen, 1967). The main belt of sandstone development passes southward into Mexico a short distance east of Nuevo Laredo. Distribution of sandstone beds and thickness of the Wilcox are influenced greatly by a growth fault system downdropped toward the Gulf of Mexico. General reservoir quality of Eocene reservoirs decreases southward into the Burgos basin. Reported permeability is generally poor to medium, and porosity values are highly variable. Gross pay

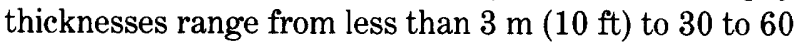
$\mathrm{m}(100-200 \mathrm{ft})$ in a few cases. Production rates range from 0.5 MMCFD or less to more than 10 MMCFD in one case. Almost all of the production is from Mount Selman sandstone and siltstone reservoirs. As of about 1970 , cumulative production from the Mount Selman was about $300 \mathrm{BCF}$ with about 50 BCF from Jackson, Yegua, and Wilcox reservoirs.

\section{SOURCE ROCKS}

Marine argillaceous rocks, interbedded with deltaic and nearshore marine sandstone reservoirs, are believed to be the main source rocks for oil and much of the gas accumulations in Tertiary reservoirs. Carbonaceous deltaic and nearshore lagoonal or swamp-deposited argillaceous beds are also probable source rocks for some of the gas.

\section{REGIONAL CAP ROCKS}

Thick and widespread marine, and in some cases nonmarine, shale facies of the Gulf basin Tertiary sequence, which intertongue with and overlie the sandy reservoir facies, form numerous regional seals for the petroleum accumulations.

\section{TRAPS}

Most traps in Burgos basin Tertiary fields are associated with combined structural-stratigraphic relationships incident to complex facies patterns of the deltaic and related nearshore environments of deposition, growth faults, and faulted domal or anticlinal folds, which in some cases may be related to deep-seated salt structures. Except in the updip beds near the outcrop belts, few of the structures are expressed at the surface.

\section{ANALOGS}

The stratigraphic and structural aspects of the Burgos basin productive province are essentially the same as those of the analogous western Gulf basin U.S. province.

\section{UPPER CRETACEOUS}

Only minor production (gas) has been found in Upper Cretaceous rocks, mainly in fractured limestone beds of the San Felipe Formation at the Lerna field in the southeastern part of the Burgos basin and in limy beds of the Eagle Ford (Boquillas) Formation at the Garza field on the northeastern flank of the Sabinas west of Nuevo Laredo (fig. 3). Gas production from fractured Eagle Ford (Boquillas) beds is also reported northwest of Nuevo Laredo on the Burro-Picachos platform (Zwanziger, 1978). These are small accumulations, and thus far prospects for significant petroleum deposits in Upper Cretaceous beds have not been promising in the Burgos and Sabinas basins. In the Burgos basin, Upper Cretaceous beds are of the open-basin shaly marine facies, probably without reservoir development, and in most cases are buried to depths greater than $7,200 \mathrm{~m}$ $(25,000 \mathrm{ft})$. The potential of the Upper Cretaceous section in the Sabinas basin is limited by the severe erosion and the probability that these beds have not been buried to thermal maturity depths, although some possibility for biogenic gas may exist in the coaly parts of the section in the Sabinas coal basin (fig. 3). The thick Upper Cretaceous sequence in the Parras and La Popa basins has not yet been explored, and several parts of this section may be attractive for gas prospects. Much of this section is an intertonguing marine and nonmarine facies with thick reservoir and potential source-rock beds, many fold and fault structures with good trap possibilities, and regional cap-rock facies. The upper part of this section has not been buried to thermal maturity depths in parts of these basins, but some of the shallower beds could be prospects for biogenic gas accumulations in the deltaic and nearshore marine facies. In the deeper parts of these basins, the lower half of the sequence has been buried to depths beyond the thermal maturity range.

\section{LOWER CRETACEOUS}

Lower Cretaceous fractured limestone and dolomite beds are productive of gas at about 10 fields in the Sabinas basin and Tamaulipas platform area. Reservoir facies are present in the carbonate beds of the Aurora Limestone, Monclova facies (upper Aurora Limestone or Actita Evaporite), Cupido Limestone and its Padilla 
Tongue, La Virgen Evaporite, and Menchaca Limestone, in sandstones of the Barril Viejo Formation, and in fractured argillaceous limestone facies of the $\mathrm{La}$ Pena Formation (fig. 2).

\section{RESERVOIRS}

The Aurora Limestone and Monclova facies are equivalent to the Stuart City Limestone of Texas, a platform and rudist bank facies of Albian Age generally present in western Coahuila in the vicinity of the Coahuila platform (fig. 10). Good porosity is observed in outcrops of these beds (Gonzalez Garcia, 1979), and the potential for matrix and fracture porosity and permeability is good where structures in the area are covered by Upper Cretaceous shaly beds.

The La Pena argillaceous limestone or shale is present throughout northeastern Mexico (fig. 2). These beds are fractured reservoirs in the Sabinas basin and Burro-Picachos platform areas.

The Cupido (and its stratigraphic equivalent in Texas, the Sligo) platform limestone facies covers much of the Sabinas basin, Tamaulipas platform, and thrust belt area and contains the major shelf margin rudist reef and mound belt of the Lower Cretaceous. Gas shows are reported from these beds (Gonzalez Garcia, 1979), and although good matrix porosity has not been observed in wells drilled so far, fractured reservoirs are a good possibility as is the local development of matrix porosity in reef or back-reef dolomitized beds.

The limestone, dolomite, and evaporite beds of the La Virgen Evaporite are a platform interior facies equivalent to the platform margin facies of the Cupido Limestone (figs. 2, 5, 6). These beds are productive in the Buena Suerte, Monclova, and Ulua gas fields (fig. 3) from porous, finely crystalline dolomite beds, which are interbedded with nonporous limestone and anhydrite beds. The La Virgen is in facies relationship with the La Mula Shale, which is a probable good sourcerock facies. Fracturing is an important factor in reservoir quality because of the fine-grained and generally low matrix permeability of the dolomites.

The Padilla Tongue represents a relatively widespread platform limestone tongue of the lower Cupido, which underlies and intertongues with the La Virgen Evaporite and La Mula Shale (figs. 2, 5, 6). The Padilla contains a thick section (up to $80 \mathrm{~m} ; 260 \mathrm{ft}$ ) of porous dolomitized reef and back-reef facies with good reservoir quality (Gonzalez Garcia, 1979); the section has been saltwater bearing in several wells.

The Barril Viejo Formation, Patula Tongue, and San Marcos Arkose are a continental to marine coarse clastic facies present in the central and southwestern part of the Sabinas basin and adjacent areas. The sandstone, carbonate, and shale beds of the Barril Viejo Formation underlie the Padilla Tongue of the Cupido in the central part of the Sabinas basin. These beds grade westward into parts of the San Marcos and Patula Arkoses. The sandstone units of the Barril Viejo are of interest as potentially good reservoirs, although lack of control prevents a complete assessment at this time. Good gas shows are reported in Barril Viejo sandstones in the Colmar No. 1 and Dolomita No. 1 wells (Gonzalez Garcia, 1979).

The Menchaca Limestone is the basal Cretaceous shelf limestone and marl unit in the central and northern parts of the Sabinas basin. These beds grade eastward into marly and sandy beds of the Taraises Formation and southward into the lower San Marcos Arkose. Fractured Menchaca Limestone flowed gas under high pressure for a short time at the Buena Suerte No. 1 well (fig. 4), but the test was considered inconclusive (Gonzalez Garcia, 1979).

\section{SOURCE ROCKS}

Potential Lower Cretaceous source rocks are present in the La Pena, La Virgen, La Mula, Barril Viejo, Menchaca, and Taraises Formations. All these formations are marine shale or shaly carbonate beds with varying amounts of organic content. In most cases, they are in stratigraphic association with potential reservoir beds. Geochemical data are not available on any of the Cretaceous units, and in places the Lower Cretaceous rocks may not have been buried to thermal maturity depths. However, in areas where the Upper Cretaceous beds are present, the Lower Cretaceous section should have been buried to sufficient depth, particularly in the southern part of the area north and east of the Sierra Madre Oriental fold and thrust belt and in most of the Sabinas basin.

\section{REGIONAL CAP ROCKS}

Impermeable regional facies that are suitable as seals for Lower Cretaceous reservoirs include the widespread Upper Cretaceous argillaceous beds and the Lower Cretaceous shale and shaly carbonate beds of the La Pena Shale, upper Tamaulipas Formation, La Virgen Evaporites, La Mula Shale, and the Barril Viejo Formation and Menchaca Limestone. These units vary in regional distribution, but in general several of them are present in most parts of the assessment area.

\section{TRAPS}

Thus far, gas discoveries in the Sabinas basin and adjacent area are on anticlinal structures, most of them 
faulted and most with large closures. Many similar structures are as yet undrilled; some are intruded by salt or gypsum but many may not be. Many potential fault and fractured reservoir traps should be present on the flanks of large structures. Facies changes are common in the Lower Cretaceous section with good possibility of stratigraphic traps; many of the accumulations appear to be combination structure, fracture pattern, and stratigraphic traps. Probably the most favorable structures are those over which the Upper Cretaceous shaly section is preserved. Accumulations may depend on the specific combination of the above factors.

\section{ANALOGS}

Stratigraphic analogs for the Lower Cretaceous section are found in much of the carbonate and evaporite section of similar age in the U.S. Gulf basin, the Tampico basin, and the southeastern Mexico-Guatemala basins. Structural styles in these areas are in the main somewhat different from those of the Sabinas and associated basin and uplift areas, where the structural styles are more directly related to the effects of Laramide folding and thrusting of the Sierra Madre Oriental. However, similarities are found in the presence of evaporite intrusion structures in some cases and in the high degree of fracturing in tightly folded structures. An important difference between the northeastern Mexico Mesozoic provinces and those of other Mesozoic productive regions of the Gulf of Mexico is the absence or thinning by erosion or nondeposition of the Upper Cretaceous and Tertiary cover in the Sabinas basin and related basins and uplifts.

\section{JURASSIC}

\section{RESERVOIRS}

The La Casita Formation contains sandstone and siltstone units, which are interbedded with high-organic shale beds in much of the Sabinas basin area. The sandstone facies is best developed in the vicinity of the Coahuila platform and the Tamaulipas platform paleostructures. Sandstone beds in the La Casita are productive of gas in the Lampazos field (fig. 3) and have had good gas shows in several other wells. The sandstones are composed of calcite-cemented quartz and carbonate grains, and interstitial porosity thus far has been low. However, their reservoir quality may improve in other parts of the basin depending on facies changes and paleostructure position. Fracturing also is important on the tightly folded Sabinas basin structures.

The Upper Jurassic Zuloaga Limestone includes the oolitic carbonate beds and evaporites of the Upper Ju- rassic Olvido Formation. The Zuloaga is present in the central part of the Sabinas basin and grades into the sandy facies of the La Gloria Sandstone around the basin borders. The oolitic beds of the Zuloaga so far have not been porous where drilled, but facies changes could improve porosity, and fracturing is important on structural prospects. The La Gloria Sandstone beds are also of potential reservoir quality, although they are suspected in most areas to have low matrix porosity.

The presalt redbed clastics are probably widespread in the area and may be very thick in downwarped graben areas of the basement. Good matrix porosity and adequate associated source rocks would not be expected in this facies, but in anomalous structural situations they could be of interest.

\section{SOURCE ROCKS}

The Upper Jurassic La Casita Formation contains a substantial thickness (as much as $310 \mathrm{~m} ; 1,000 \mathrm{ft}$ or more) of dark organic shaly beds which underlie the Cretaceous section throughout most of the Sabinas basin. The La Casita has been buried to depths of more than $4,600 \mathrm{~m}(15,000 \mathrm{ft})$ in parts of the basin area, and there is some indication that these beds may have undergone severe thermal alteration (Gonzalez Garcia, 1979). Igneous activity, as well as burial depths, may have also contributed to the thermal effects. Excessive thermal activity may explain the high methane and $\mathrm{CO}_{2}$ content of most of the gases, as well as the lack of significant oil indications in the fields discovered so far. In addition, there seems to be evidence that the basin is primarily a dry-gas basin. Condensate and some oil shows, however, have been encountered in a few wells, and current drilling density precludes an accurate assessment of these factors.

The Zuloaga Limestone, which is reported as black and argillaceous in places, may also contain a less important Upper Jurassic source-rock facies.

\section{TRAPS}

Petroleum deposits in Jurassic reservoir beds should be associated with the same kinds of traps as those of the Lower Cretaceous reservoirs that occur in folded and faulted structures having an important fractured reservoir factor and some possibility of stratigraphic trapping, particularly on the flanks of large structures.

\section{ANALOGS}

The Jurassic stratigraphic section in northeastern Mexico is similar in most respects to that of the north- 
ern regions of the U.S. Gulf basin, except that the carbonate beds in the Zuloaga Formation do not appear to contain porous reservoir facies as extensive as those of the Smackover Formation. The La Casita and La Gloria beds are similar in most respects to clastic facies of the Cotton Valley Group in the northern Gulf basin and contain a significant thickness of dark high-organic facies and sandstone beds similar to equivalent productive reservoirs in Texas and Louisiana.

\section{RESOURCE ASSESSMENT}

\section{PROCEDURES}

The resource assessment was conducted by the Resource Appraisal Group (RAG) of the U.S. Geological Survey, Branch of Oil and Gas Resources, following the standard procedures developed since 1974 for domestic petroleum resource analysis. The technique, briefly, requires study of a given area paying particular attention to the geologic factors controlling the occurrence, quality, and quantity of the petroleum resource. Standardization of critical elements of the investigations is achieved by the preparation of data forms for each basin; the forms call for specific volumetric, areal, and rock-quality measurements, as well as the determination of basin analogs for comparison purposes. In addition, finding-rate histories and projections are constructed when possible. From these data and analyses, various analytical techniques are used to calculate a set of resource numbers. Not considered in this assessment are resources of heavy oil deposits, tar deposits, and oil shales; gas in low-permeability reservoirs, in geopressured shales and brines, and in natural gas hydrates; and gas occluded in coal.

The assessment process itself is subjective; the results of the geological investigation and of the resource calculations are presented to a team of U.S. Geological Survey assessment specialists who make their personal estimates conditional upon recoverable resources being present. Initial assessments are made for each of the assessed provinces as follows:

(a) A low resource estimate corresponding to a 95percent probability of more than that amount; this estimate is the 95 th fractile $\left(\mathrm{F}_{95}\right)$.

(b) A high resource estimate corresponding to a 5percent probability of more than that amount; this estimate is the 5 th fractile $\left(\mathrm{F}_{5}\right)$.

(c) A modal ("most likely") estimate of the quantity of resource associated with the greatest likelihood of occurrence.

The individual estimates are then posted and averaged, and the results debated from the perspective of the personal experiences of the individual assessors; a second and third iteration of the procedure may follow depending on consensus. If no commercial oil has been heretofore discovered in the basin, then a marginal probability is subjectively assessed reflecting the probability that any commercial oil will ever be discovered.

The results of the final estimates are averaged, and those numbers are computer processed using probabilistic methodology (Crovelli, 1981) to show graphically the resource values associated with a full range of probabilities and to determine the 95 th fractile, the 5 th fractile, and the mean, as well as other statistical parameters.

\section{ASSESSMENT}

The locations of the northeastern Mexico basins are shown in figure 1. Unconditional estimates by the U.S. Geological Survey of oil and gas resources in these basins are given in table 1 and figures 13 and 14. Data and summary information supporting these estimates are supplied in tables $2-4$.

TABLE 1.-Estimates of conventionally recoverable petroleum resources of northeastern Mexico, including those of the Sabinas, Parras, and Burgos basins

[Unconditional resource assessment by U.S. Geological Survey as of June 23, 1981; see also figures 13 and 14$]$

\begin{tabular}{|c|c|c|c|c|c|}
\hline \multicolumn{3}{|c|}{$\begin{array}{c}\text { Crude oil } \\
\text { in billions of barrels }\end{array}$} & \multicolumn{3}{|c|}{$\begin{array}{l}\text { Natural gas } \\
\text { in trillions of cubic feet }\end{array}$} \\
\hline \multicolumn{6}{|c|}{ Probability of occurrence (percent) } \\
\hline 95 & 5 & Mean & 95 & 5 & Mean \\
\hline \multicolumn{6}{|c|}{ Sabinas and Parras basins ${ }^{1}$} \\
\hline 0 & 2.9 & 0.8 & 18 & 122 & 55 \\
\hline \multicolumn{6}{|c|}{ Burgos basin } \\
\hline 0.1 & 1.2 & 0.5 & 1.6 & 12.5 & 5.5 \\
\hline \multicolumn{6}{|c|}{ Combined Sabinas, Parras, and Burgos basins ${ }^{2}$} \\
\hline \multirow[t]{3}{*}{0.2} & 3.5 & 1.3 & 23 & 126 & 61 \\
\hline & & & \multicolumn{3}{|c|}{$\begin{array}{c}\text { BBOE at } \\
6,000 \mathrm{ft}^{3} / \text { barrel }^{*}\end{array}$} \\
\hline & & & 4 & 21 & 10 \\
\hline $\begin{array}{l}\text { A margi } \\
\text { hese basi } \\
\text { Totals ar } \\
\text { of the com } \\
\text { In PEM }\end{array}$ & $\begin{array}{l}\text { prob } \\
\text { erive } \\
\text { ent } \\
\text { repo }\end{array}$ & $\begin{array}{l}\text { lity of } 0.85 \\
\text { y statistice } \\
\text { s. } \\
\text { conversio }\end{array}$ & ; only th & ence of $c$ & $\begin{array}{l}\text { mercial oi } \\
\text { quals the }\end{array}$ \\
\hline
\end{tabular}




\section{COMMENTS}

- Exploration in the Sabinas basin is in its very initial stages. So far, we have reports on four successful wildcats, each of which is reported to be capable of production in excess of $10,000,000 \mathrm{ft}^{3} / \mathrm{d}$. Though no oil has yet been reported, the geologic investigation suggests that oil in some part of the basin is likely.

- Giant fields are likely in the Sabinas and Parras basins owing to structural development, including salt and probable favorable Jurassic source rock. Overall stratigraphic thickness of Mesozoic units may be 30,000 to $40,000 \mathrm{ft}$.
- The Sabinas and Parras basins reflect geologic conditions similar to those in the western United States from the overthrust belt east to the North American craton. Production from Jurassic and Cretaceous units will predominate.

- The Burgos basin is an extension of the U.S. Western Gulf basin. Substantial production has been established from lower Tertiary rocks on both sides of the U.S.-Mexico border. Production from Eocene and Oligocene rocks will predominate.

- Giant fields are not likely in the Burgos basin owing to the state of maturity for exploration and the deltaic environment. Overall stratigraphic thickness of Tertiary rocks may exceed $50,000 \mathrm{ft}$.

TABLE 2.-Data and information summary

Geologic province: Mesozoic and Tertiary continental basins.

Areas included in assessment:

Burgos basin

Sabinas basin and adjacent uplifts

Parras, La Popa, and Magiscatzin basins

Northern and eastern borders of Sierra Madre Oriental overthrust belt.

Total area of province: $330,000 \mathrm{~m}^{2}\left(125,000 \mathrm{mi}^{2}\right)$

Prospective intervals:

Tertiary continental-marine clastic sequence, Burgos basin.

Upper Cretaceous continental-marine clastic sequence, Parras, La Popa, and southern Sabinas basins.

Lower Cretaceous marine platform carbonate sequence, Sabinas, Parras, La Popa, and Magiscatzin basins; Burro-Picachos, Tamaulipas, and Coahuila platforms and Sierra Madre Oriental overthrust belt.

Upper Jurassic marine clastic and carbonate sequence

Pre-Upper Jurassic continental-marine clastic and evaporite sequence.

Source beds:

Tertiary marine, lagoonal, and deltaic carbonaceous shales and siltstones.

Upper Cretaceous marine and deltaic carbonaceous shales and siltstones.
Lower Cretaceous marine organic shale and argillaceous limestone.

Upper Jurassic marine organic shale and argillaceous limestone.

Prospective trap types:

Tertiary and Upper Cretaceous marine, deltaic, and continental sandstones.

Cretaceous and Jurassic reef, back reef, and fracture pattern porosity-permeability variations.

Asymmetric, thrust-faulted, and normal faulted anticlines and domes, some related in part to salt or gypsum movement.

Combination structural and stratigraphic traps

Exploration stage of province: Mature in Tertiary Burgos basin; early in province.

Number of fields: About 90 small to intermediate gas and gas-condensate fields in Burgos basin; about 10 dry gas fields in Sabinas basin and adjacent Burro-Picachos platform, some of which may be large.

Cumulative production: About 4 TCF gas and $100 \mathrm{MMB}$ condensate and oil.

Average depth of undiscovered resources: About 4,500-6,000 m $(15,000-20,000 \mathrm{ft})$ in Burgos basin; about 3,300-4,500 m $(10,000-15,000 \mathrm{ft})$ in Sabinas-Parras-La Popa basins.

Recoverable basin richness: At mean, undiscovered estimate assuming $330,000 \mathrm{mi}^{3}$ of sediments $=43,000 \mathrm{BOE} / \mathrm{mi}^{3}$.

Analogs: Gulf basin, United States; Tampico basin, Mexico 


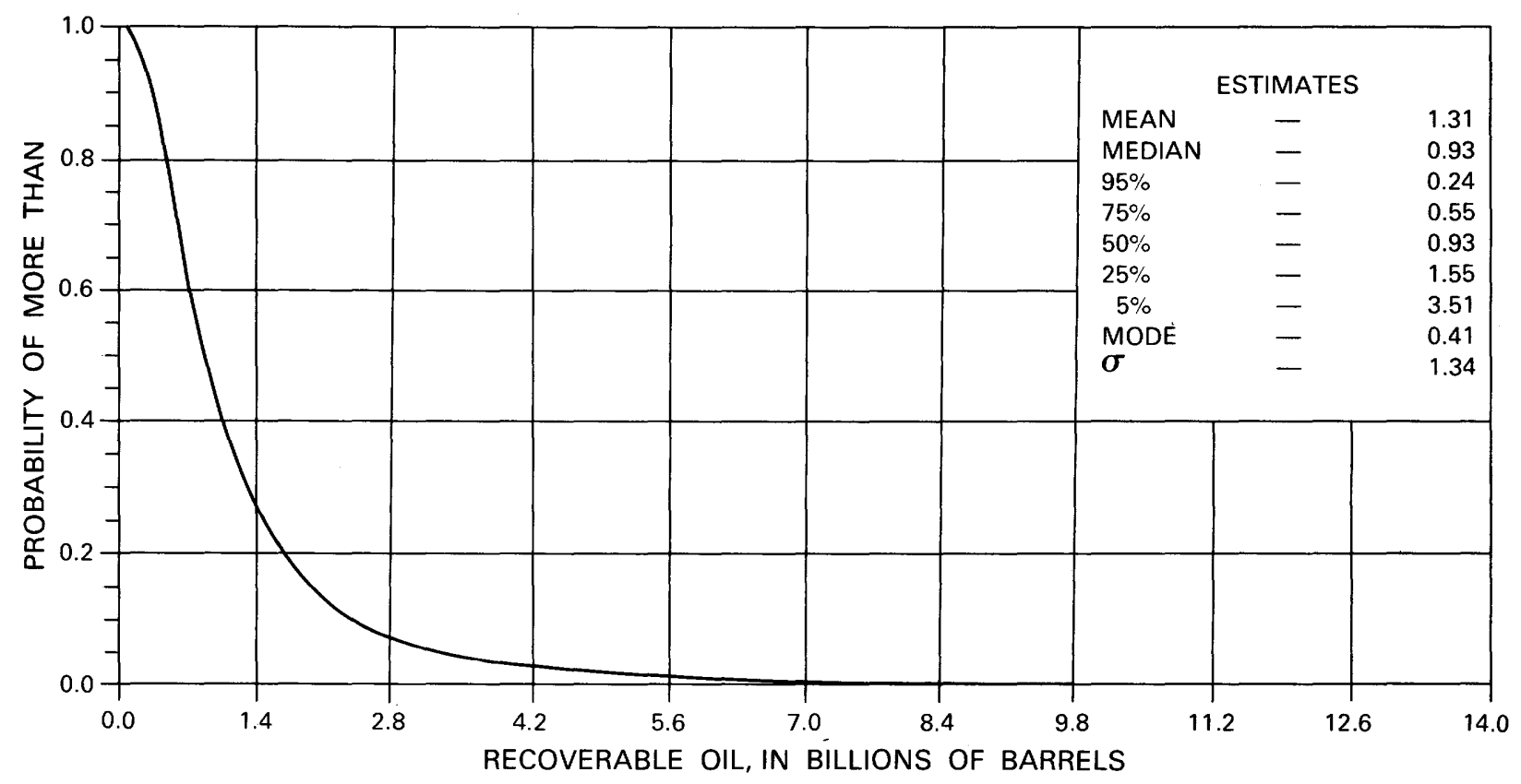

FIGURE 13.--Aggregate recoverable oil in the Burgos and Sabinas-Parras basins, Mexico.

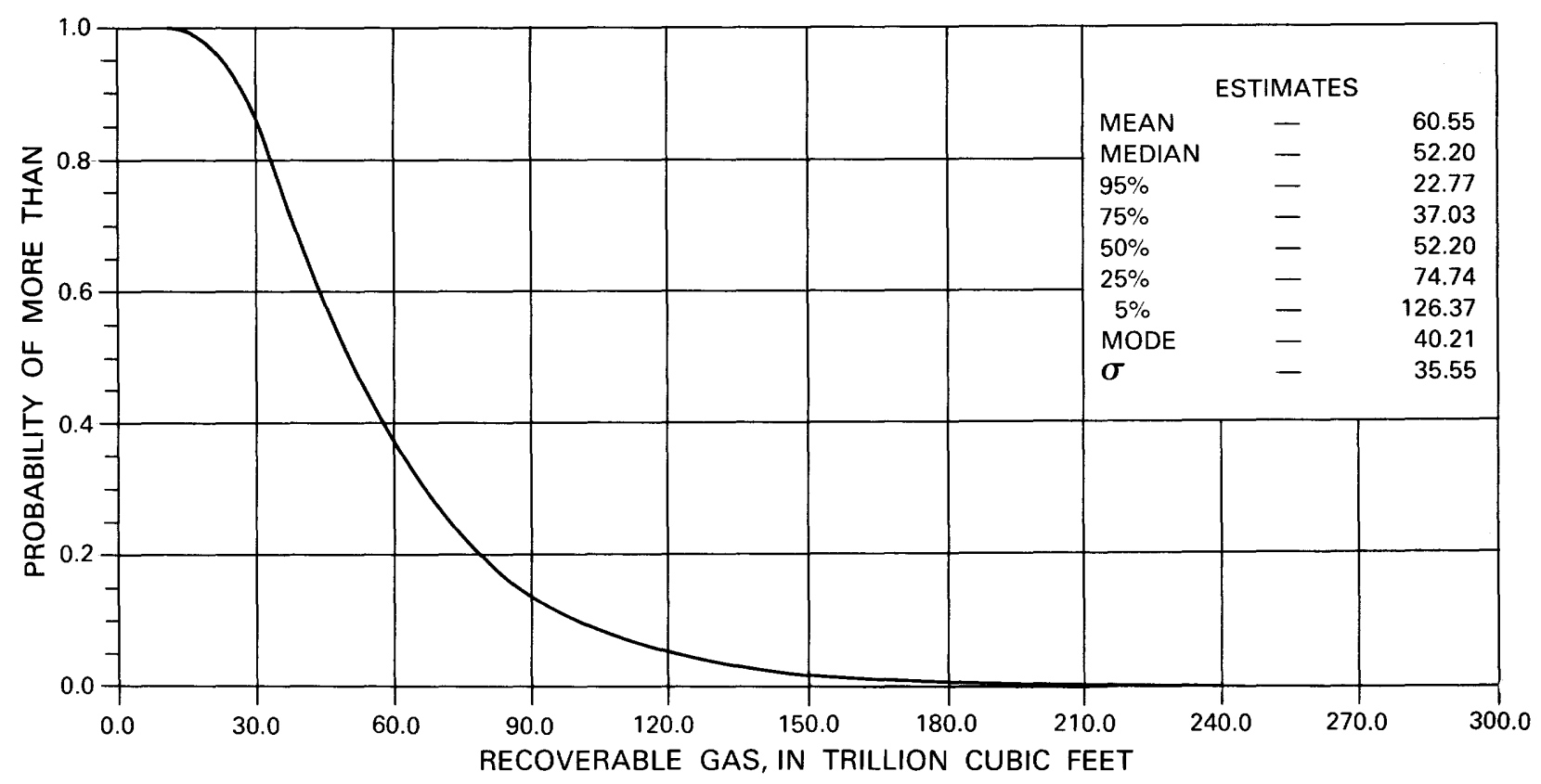

Figure 14.-Aggregate recoverable total gas in the Burgos and Sabinas-Parras basins, Mexico. 


\begin{tabular}{|c|c|c|}
\hline & Burgos basin & Sabinas basin area \\
\hline Source rocks & $\begin{array}{l}\text { Tertiary marine shales, mainly gas; Cretaceous } \\
\text { and Upper Jurassic marine black shales and } \\
\text { shaly carbonates. }\end{array}$ & $\begin{array}{l}\text { Upper Jurassic black shales; Lower and middle } \\
\text { Cretaceous gray and black shales and shaly } \\
\text { limestones; Upper Cretaceous marine gray } \\
\text { shales. }\end{array}$ \\
\hline Structure & $\begin{array}{l}\text { Anticlines and domes, faulted, and vertical faults; } \\
\text { possibly deep salt-structure influence. }\end{array}$ & $\begin{array}{l}\text { Elongate anticlines and regional uplifts, many } \\
\text { evaporite structures; common vertical faults; } \\
\text { major thrust belt in south part. }\end{array}$ \\
\hline Paleostructure & $\begin{array}{l}\text { General continental border basin subsidence with } \\
\text { down-to-gulf growth faults. }\end{array}$ & $\begin{array}{l}\text { Regional Mesozoic paleostructures inherited from } \\
\text { Paleozoic; major continental border evaporite } \\
\text { basin subsidence in center; Laramide thrust } \\
\text { belt growth in south part. }\end{array}$ \\
\hline $\begin{array}{l}\text { Time of migration } \\
\text { and } \\
\text { hydrocarbon } \\
\text { generation }\end{array}$ & Good. & Good. \\
\hline $\begin{array}{l}\text { Geothermal } \\
\text { gradient }\end{array}$ & Normal. & $\begin{array}{l}\text { Probably high in parts of area, particularly } \\
\text { western part, because of Cenozoic igneous } \\
\text { activity and overthrust activity. }\end{array}$ \\
\hline $\begin{array}{l}\text { Preservation } \\
\text { history }\end{array}$ & Good. & $\begin{array}{l}\text { Upper Cretaceous exposed over much of area; } \\
\text { Lower and middle Cretaceous exposed in } \\
\text { main structural areas; Upper Jurassic } \\
\text { exposed in small areas of main salt anticlines } \\
\text { and in parts of south thrust belt. }\end{array}$ \\
\hline Size of area & $\begin{array}{l}\text { Small-14,000 } \mathrm{mi}^{3}, 113,000 \mathrm{mi}^{3} \text { of sediment; } \\
\text { about } 1 / 8 \text { the size of western U.S. Gulf basin. }\end{array}$ & $\begin{array}{l}\text { Intermediate }-80,000 \mathrm{mi}^{2}, 218,000 \mathrm{mi}^{3} \text { of } \\
\text { sediment; slightly smaller than Permian } \\
\text { basin of Midcontinent areas, United States. }\end{array}$ \\
\hline Exploration stage & $\begin{array}{l}\text { Mature, except in deep part of basin where } \\
\text { probability of good reservoir section is low. }\end{array}$ & $\begin{array}{l}\text { Early; } 65 \text { or more important structures are as yet } \\
\text { undrilled. }\end{array}$ \\
\hline
\end{tabular}


TABLE 4.-Supplementary and comparative data supporting the resource estimates for northeastern Mexico ${ }^{1}$

Crude oil Natural gas (billion barrels) (trillion cubic feet)

Cumulative production to Jan. 1, 1980

\begin{tabular}{|c|c|}
\hline Sabinas/Parras …......... 0 & +2 \\
\hline (1, & 4.0 \\
\hline
\end{tabular}

Measured reserves ${ }^{3}$ to Jan. 1,1980

\begin{tabular}{lll}
\hline Sabinas/Parras ............ & 0 & $+{ }^{2}$ \\
Burgos $\ldots \ldots \ldots \ldots \ldots \ldots \ldots$ & .3 & 5.0 \\
\hline
\end{tabular}

Original recoverable resources (ultimate) of the two basins

\begin{tabular}{|c|c|c|}
\hline & Oil & $\begin{array}{c}\text { BBOE at } \\
6,000 \mathrm{ft}^{3} / \text { barrel } \\
\end{array}$ \\
\hline Cumulative production & 0.1 & $4.0+$ \\
\hline Identified reserves & .3 & $5.0+$ \\
\hline $\begin{array}{l}\text { Undiscovered resources } \\
\text { (mean) }\end{array}$ & 1.3 & $\underline{61.0}$ \\
\hline Total $\ldots$ & 1.7 & $\begin{array}{l}70.0+ \\
12+\end{array}$ \\
\hline Tota & $4+$ & \\
\hline
\end{tabular}

Recoverable basin richness: At mean, undiscovered estimate assuming $330,00 \mathrm{mi}^{3}$ of sediments $=43,000 \mathrm{BOE} / \mathrm{mi}^{3}$.

1 Cumulative production and reserves are composited estimates from various sources.

2 Quantity positive, but data unavailable.

3 Follows terminology outlined in "Principles of a Resource/Reserve Classification for Minerals," 1980, U.S. Geological Survey Circular 831. by U.S. Bureau of Mines and U.S. Geological Survey, 5 p.

\section{SELECTED REFERENCES}

Alvarez, M., Jr., and Mina, F., 1951, Mexico: American Association of Petroleum Geologists Bulletin, v. 35, p. 361-384.

Barker, C. L., 1936, Upper Jurassic deposits and structures of the Monterrey Saltillo area: South Texas Geological Society Guidebook 13th Annual Meeting, 4 p.

Bebout, D. G., 1977, Sligo and Hosston depositional patterns, subsurface of south Texas, in Cretaceous carbonates of Texas and Mexico: Texas Bureau of Economic Geology Report Investigations No. 89, p. 79-96.

Beebe, B. W., 1968, Occurrence of natural gas in Mexico, in Natural Gases of North America: American Association of Petroleum Geologists, Memoir 9, v. 1, p. 209-232.

Bishop, W. F., 1970, Stratigraphy of Sierra de Picachos: American Association of Petroleum Geologists Bulletin, v. 54, p. 1245-1270.

1972, Petrography and origin of Cretaceous limestones, Sierra de Picachos and vicinity, Nuevo Leon, Mexico: Journal of Sedimentary Petrology, v. 42, p. 270-286.
Bonet, F., 1956, Zonification microfaunistica de las Calizas Cretacicas del este de Mexico [Microfaunal zonation of the Cretaceous limestones of eastern Mexico]: Twentieth International Geologic Congress, $102 \mathrm{p}$.

Bose, E., 1923, Vestiges of an ancient continent in northeast Mexico: American Journal of Science, 5th Series, v. 206, p. 127-136, 196-214, 310-337.

Carillo-Bravo, J., 1961, Geologia del Anticlinorio Huizachal-Peregrina al N-W de Ciudad Victoria Tamps. [Geology of the Huizachal-Peregrina anticlinorium northwest of Ciudad Victoria, Tamaulipas]: Association Mexicana Geologos Petroleros Boletin, v. 13, p. 1-98.

1963 , Geology of the HuizachalPeregrina anticlinorium northwest of Ciudad Victoria, Tamaulipas, in Geology of Peregrina Canyon and Sierra del Abra, Mexico: Corpus Christi Geological Society Annual Field Trip, 1963, p. 11-25.

1965, Estudio geologico de una parte del Anticlinorio de Huayacocotla: [Geological study of a part of the Huayacocotla Anticlinorium]: Association Mexicana Geologos Petroleros Boletin, v. 17 , p. 73-96.

Charleston, S., 1974, Stratigraphy, tectonics, and hydrocarbon potential of the Lower Cretaceous, Coahuila, Mexico: Unpublished University of Michigan Ph.D. dissertation, $268 \mathrm{p}$.

1981, A summary of the structural geology and tectonics of the State of Coahuila, Mexico, in Lower Cretaceous stratigraphy and structure, Northern Mexico: West Texas Geological Society, no. 81-74, p. 28-36.

Claughton, J. L., 1978, Geology of the lower part of the Wilcox Group, Webb and Zapata Counties, Texas, in Minas de Golondrinas and Minas Rancherias, Northeastern Mexico: Corpus Christi Geological Society, 1978 Spring Field Conference, p. 13-26.

Conklin, J., and Moore, C., 1977, Paleoenvironmental analysis of the Lower Cretaceous Cupido Formation, northeast Mexico, in Cretaceous carbonates of Texas and Mexico: Texas Bureau of Economic Geology, Report Investigations, no. 89, p. 302-323.

Corpus Christi Geological Society, 1978, Spring Field Conference, Minas de Golondrinas and Minas Rancherias, northeastern Mexico, $48 \mathrm{p}$.

1979, Spring Field Conference, Portrero Garcia and Huasteca Canyon, northeastern Mexico, $46 \mathrm{p}$.

Crovelli, R. A., 1981, Probabilistic methodology for oil and gas resource appraisal: U.S. Geological Survey Open-File Report 81-1151, $77 \mathrm{p}$.

Cserna, Z. de, 1970, Mesozoic sedimentation, magmatic activity and deformation in northern Mexico, in The geologic framework of the Chihuahua Tectonic Belt, Symposium: West Texas Geological Society, p. 99-117.

Daugherty, F. W., 1963, Basement rocks of Pico Etereo area, Municipio de Acuna, Coahuila, Mexico: American Association of Petroleum Geologists Bulletin, v. 47, p. 1746-1747.

Daugherty, F. W., and Powell, D. J., 1963, Late Cretaceous stratigraphy in northern Coahuila, Mexico: American Association of Petroleum Geologists Bulletin, v. 47, p. 2059-2064.

Diaz, G. T., 1956, Estratigrafia del Cenozoico del Mesozoico a lo largo de la Carretera entre Reynosa, Tamps., y-Mexico, D. F., ruta Monterrey, N. L., Cd. Victoria, Tamps. [Stratigraphy of the Cenozoic and Mesozoic along the highway between Reynosa, Tamps, and Mexico, D.F., through Monterrey, N.L. and ed, Vuctiruam Tamps.]: Twentieth International Geological Congress, Excursions A-14 y C-16.

Ekdale, A., Ekdale, S. R., and Wilson, J. L., 1976, Numerical analysis of carbonate microfacies in the Cupido Limestone (NeocomianAptian), Coahuila, Mexico: Journal of Sedimentary Petrology, v. 46, p. $362-368$. 
Enos, P., 1974, Reefs, platforms, and basins of Middle Cretaceous in northeast Mexico: American Association of Petroleum Geologists Bulletin, v. 58, p. 800-809.

Erben, H. K., 1956, El Jurasico Medio y el Calloviano de Mexico [The Middle Jurassic and the Callovian of Mexico]: Mexico, D. F., International Geologic Congress, 20th, 1956, 140 p.

1957, Paleographic reconstructions for the Lower and Middle Jurassic and for the Callovian of Mexico, in El Mesozoico del Hermisferio Occidental y sus correlaciones mundiales: International Geologic Congress, 20th, Mexico, D. F., 1956 (Trabajos), sec. 2, p. 35-41.

Fisher, W. L., and McGowen, J. H., 1967, Depositional systems in the Wilcox Group of Texas and their relationship to occurrence of oil and gas: Gulf Coast Association Geological Societies, Transactions, v. 17, p. 105-125.

Fisher, W. L., and Rodda, P. U., 1969, Edwards Formation (Lower Cretaceous) Texas; dolomitization in a carbonate platform system: American Association of Petroleum Geologists Bulletin, v. 53 , p. 55-72.

Flawn, P. T., and Diaz, T., 1959, Problems of Paleozoic tectonies in north-central and northern Mexico: American Association of Petroleum Geologists Bulletin, v. 43, p. 224-230.

Flawn, P. T., and Maxwell, R. A., 1958, Metamorphic rocks in Sierra del Carmen, Coahuila, Mexico: American Association of Petroleum Geologists Bulletin, v. 42, p. 2245-2249.

Garza, F. R., 1973, Modelo sedimentario del Albiano-Cenomaniano en la porcion SE de las Platforma de Coahuila [Sedimentary model of the Albian-Cenomanian in the area southeast of the Coahuila Platform]: Association Mexicana de Geologos Petroleros Boletin, v. 25, p. 7-9.

Gonzalez Garcia, R., 1979, Exploracion petrolera en el "Golfo de Sabinas" nueva provincia productora de gas [Petroleum exploration in the "Gulf of Sabinas" new gas producing province]: Ingenieria Petrolera, Febero de 1979, p. 28-36.

Guzman, E. J., 1949, New petroleum development by Petroleos Mexicanos in northeastern Mexico: American Association of Geologists Bulletin, v. 33, p. 1351-1384.

Guzman, E. J., and Cserna, Z. de., 1963, Tectonic history of Mexico, in Backbone of the Americas, a symposium: American Association of Petroleum Geologists, Memoir 2, p. 113-120.

Guzman, E. J., Saurez, R., and Lopez-Ramos, E., 1955, Outline of the petroleum geology of Mexico: Proceedings of Conference on Latin American Geology, University of Texas, p. 1-30.

Harvill, L. H., 1978, Structural and geomorphic development of northern Nuevo Leon, Mexico, in Minas de Golondrinas and Minas Rancherias, Northeastern Mexico: Corpus Christi Geological Society, 1978 Spring Field Conference, p. 39-42.

Holcomb, C. W., 1971, Hydrocarbon potential of Gulf Series of western Gulf basin, in Future petroleum provinces of the United States-Their geology and potential: American Association of Petroleum Geologists, Memoir 15, p. 887-900.

Humphrey, W. E., 1949, Geology of the Sierra de los Muertos area, Mexico: American Association of Petroleum Geologists Bulletin, v. 60 , p. $89-176$.

1956. Tectonic framework of northeast Mexico, in Gulf Coast Association Geological Societies, Transactions, v. 6, p. 25-36.

Humphrey, W. E., and de Cserna, Z., 1956, Study of the Mesozoic stratigraphy and the tectonics of the Sierra Madre Oriental between Monterrey, N. L., and Torreon, Coah.: 20th International Geological Congress, Excursion C-5, 111 p.

Imlay, R. W., 1936, Geology of the western part of the Sierra de Parras: Geological Society of America Bulletin, v. 47, p. 1723-1744.
1938, Ammonites from the Taraises Formation of northern Mexico: Geological Society of America Bulletin, v. 49, p. 539-602.

1940, Neocomian faunas of northern Mexico: Geological Society of America Bulletin, v. 51, p. 117-190.

1943, Jurassic formations of Gulf region: American Association of Petroleum Geologists Bulletin, v. 27, p. 1407-1533.

1944, Cretaceous formations of Central America and Mexico: American Association of Petroleum Geologists Bulletin, v. 29, p. 1416-1469.

1953, Las formaciones jurasicas de Mexico [Jurassic formations of Mexico]: Society Geologia Mexicana Boletin, v. 16, p. $1-65$.

1980 , Jurassic paleobiogeography of the conterminous United States in its continental setting: U.S. Geological Survey Professional Paper 1062, 134 p.

Imlay, R. W., Cepeda, E., Alvarez, M., Jr., and Diaz-Gonzalez, T. E., 1948, Stratigraphic relations of certain Jurassic formations in eastern Mexico: American Association of Petroleum Geologists Bulletin, v. 32, p. 1750-1761.

Jones, R. A., 1925, A reconnaissance study of the Salado Areh, Nuevo Leon and Tamaulipas, Mexico: American Association of Petroleum Geologists Bulletin, v. 9, p. 123-133.

Jones, T. S., 1938, Geology of the Sierra de la Pena and paleontology of the Indidura Formation, Coahuila, Mexico: Geological Society of America Bulletin, v. 49, p. 61-150.

Kane, W. G., 1936, Evolution of the Coahuila Peninsula, Mexico: Geological Society of America Bulletin, v. 47, p. 969-1176.

Kane, W. G., and Gierhart, G. B., 1935, Areal geology of the Eocene in north-eastern Mexico: American Association of Petroleum Geologists Bulletin, v. 19, p. 1357-1388.

Kelley, W. A., 1936, Evolution of the Coahuila Peninsula; Part II, Geology of the mountains bordering the valley of Acatitla and Delicias: Geological Society of America Bulletin, v. 47.

Kellum, L. B., Imlay, R. W., and Kanes, W. G., 1936, Evolution of the Coahuila Peninsula, Mexico, part 1: Geological Society of America Bulletin, v. 47, p. 969-1008.

Krutak, P. R., 1965, Source areas of the Patula Arkose (Lower Cretaceous) Coahuila: Journal Sedimentary Petrology, v. 35, p. 512-517.

Lofton, C. L., and Adams, W. M., 1971, Possible future petroleum provinces of Eocene and Paleocene, western Gulf basin, in Future petroleum provinces of the United States-Their geology and potential: American Association of Petroleum Geologists Memoir 15, p. 855-884.

Lopez-Ramos, E., 1969, Marine Paleozoic rocks of Mexico: American Association of Petroleum Geologists Bulletin, v. 53, p. $2 \% 99-2417$.

1980, Geologia de Mexico [Geology of Mexico], Tomo II, 2d Edicion: E. Lopez-Ramos, Mexico, D. F., p. 187-453.

Masters, C. D., and Peterson, J. A., 1981, Assessment of conventionally recoverable petroleum resources of northeastern Mexico: U.S. Geological Survey Open-File Report 81-143, 7 p.

McBride, E. F., Weidie, J. A. Wolleben, J. A., and Laudon, R. C., 1974, Stratigraphy and structure of the Parras and La Popa basins, northeastern Mexico: Geological Society of America Bulletin, v. 84, p. 1603-1622.

McFarlan, E., 1977, Lower Cretaceous sedimentary facies and sea level changes, U.S., Gulf Coast, in Cretaceous carbonates of Texas and Mexico: Texas Bureau of Economic Geology, Report of Investigation no. 89, p. 5-11.

Mixon, R. B., 1963, Geology of the Huizachal redbeds, Ciudad Victoria area, southwestern Tamaulipas, in Geology of Peregrina Canyon and Sierra del Abra, Mexico: Corpus Christi Geological Society Annual Field Trip 1963, p. 24-35. 
Mixon, R. B., Murray, G. E., and Diaz-Gonzalez, T. E., 1959, Age and correlation of Huizachal group (Mesozoic), state of Tamaulipas, Mexico: American Association of Petroleum Geologists Bulletin, v. 43, p. 757-771.

Murray, G. E., 1961, Geology of the Atlantic and Gulf coastal province of North America: New York, Harper and Brothers, $692 \mathrm{p}$.

1966, Salt structures of Gulf of Mexico basin (review): American Association of Petroleum Geologists Bulletin, v. 50, p. 439-478.

Murray, G. E., Buis, O. J., and Durham, C. O., Jr., 1961, Geologic summary of Potrero Padilla, Coahuila, Mexico: American Association of Petroleum Geologists Bulletin, v. 45, p. 392-396.

Murray, G. E., Wolleben, J. A., and Boyd, D. R., 1959, Difunta strata of Tertiary age, Coahuila, Mexico: American Association of Petroleum Geologists Bulletin, v. 43, p. 2493-2495.

Murray, G. E., Weidie, A. E., Jr., Boyd, D. R., Forde, R. H., and Lewis, P. D., Jr., 1962, Formational divisions of Difunta Group, Parras basin, Coahuila and Nuevo Leon, Mexico: American Association of Petroleum Geologists Bulletin, v. 46, p. 374-383.

Newkirk, T. F., 1971, Possible future petroleum potential of Jurassic, western Gulf basin, in Future petroleum provinces of the United States-Their geology and potential: American Association of Petroleum Geologists, Memoir 15, p. 927-953.

Perez Fernandez, R., and Diaz Gonzales, T., 1964, Jurassic data from wells in northeastern Mexico: Gulf Coast Association Geological Societies, Transactions, v. 14, p. 231-232.

Pessagno, E. A., Jr., 1969, Upper Cretaceous stratigraphy of the western Gulf Coast area of Mexico, Texas, and Arkansas: Geological Society of America Memoir 111, $139 \mathrm{p}$.

Powell, J. D., 1965, Late Cretaceous platform, northern Mexico and adjacent Texas: American Association of Petroleum Geologists Bulletin, v. 49, p. 511-525.

Powell, L. D., and Woodbury, H. O., 1971, Possible future petroleum potential of Pleistocene, western Gulf basin, in Future petroleum provinces of the United States-Their geology and potential: American Association of Petroleum Geologists, Memoir 15, p. 813-823.

Rainwater, E. H., 1967, Resume of Jurassic to Recent sedimentation history of the Gulf of Mexico Basin: Gulf Coast Association Geological Societies Transactions, v. 17, p. 179-210.

1971, Possible future petroleum potential of Lower Cretaceous, western Gulf Basin, in Future petroleum provinces of the United States-Their geology and potential: American Association of Petroleum Geologists Memoir 15, p. 901-926.

Russell, J. L., 1978, Sedimentary, igneous, and metamorphic rocks of northern Nuevo Leon, Mexico, in Minas de Golondrinas and Minas Rancherias, northeastern Mexico: Corpus Christi Geological Society, 1978 Spring Field Conference, p. 43-50.

1979, Geology of Mamulique Pass, Nuevo Leon, Mexico, in Portrero Garcia and Huasteca Canyon, Northeastern Mexico: Corpus Christi Geological Society, 1979 Spring Field Conference, p. 19-23.

Salinas, S., 1969, Golfo de Sabinas, Jurasico Superior y Correlacion: Problemas de exploracion en areas posiblemente petroleras de la Republica Mexicana, seminario sobre exploracion petrolera [Gulf of Sabinas, Upper Jurassic and Correlation: Problems of exploration in possibly petroliferous areas of the Mexican Republic, seminar on petroleum exploration]: Mesa Redonda no. 6, Instituto Mexicano del Petroleo.

Scott, R. W., and Kidson, E. J., 1977, Lower Cretaceous depositional systems, west Texas, in Cretaceous Carbonates of Texas and Mexico: Texas Bureau of Economic Geology, Report Investigation no. 89 , p. $169-181$.
Shinn, A. D., 1971, Possible future petroleum potential of upper Miocene and Pliocene, western Gulf Basin, in Future petroleum provinces of the United States-Their geology and potential: American Association of Petroleum Geologists, Memoir 15, p. 824-835.

Smith, C. C., 1981, Calcareous nannoplankton and stratigraphy of late Turonian, coniacian, and early Santonian age of the Eagle Ford and Austin Groups of Texas: U.S. Geological Survey Professional Paper 1075, $98 \mathrm{p}$.

Smith, C. I., 1970, Lower Cretaceous stratigraphy, northern Coahuila, Mexico: University of Texas, Austin, Bureau of Economic Geology, Report Investigation no. 65, 101 p.

1971, Lower Cretaceous sedimentation and tectonics of the Coahuila and west Texas platforms, in The geologic framework of the Chihuahua Tectonic Belt: West Texas Geological Society, p. $75-82$.

1981, Review of the geologic setting, stratigraphy, and facies distribution of the lower Cretaceous in northern Mexico, in Lower Cretaceous stratigraphy and structure, northern Mexico: West Texas Geological Society, no. 81-74, p. 1-27.

Tardy, M., 1973, Sobre la Tectonica de la Sierra Madre Oriental en el sector de Parras, Coah., el cabalgamiento de la Serie Parrense [On the tectonies of the Sierra Madre Oriental in the area of Parras, Coahuila, the completion of the Parrense Series]: Society Geologia Mexicana Boletin, v. 34, p. 51-70.

1976, Estructura de la Sierra Madre Oriental (sector transversal), Edo. de Coahuila [Structure of the Sierra Madre Oriental, transverse area, State of Coahuila]: Resumenes III Conference Latinum de Geolgia, Exc. 3, Acapulco, Guerro.

Tardy, M., Ramirez, R. C., Y Patino, M., 1976, El frente de la Napa de Parras en el area de Aramberri, Nuevo Leon [The front of the Parras nappe in the area of Aramberri, Nuevo Leon]: Sierra Madre Oriental, Mexicana Revue no. 2, Instituto de Geologia, UNAM.

Tardy, M., Signal, J., y Glacon, G., 1974, Bosquejo sobre la estratigrafia y paleontologia de los flysch cretaciocos en el sector transversal de Parras, Sierra Madre Oriental [Outline on the stratigraphy and paleontology of the Cretaceous flysch in the area transverse of Parras, Sierra Madre Oriental]: Serie Divulgacion no. 2, Institut Geologia UNAM, p. 1-72.

1975, Observaciones generales sobre la estructura de la Sierra Madre Oriental; La aloctonia del Conjunto Cadena Alta, Altiplano Central entre Torreon y San Luis Potosi, Mexico [General observations on the structure of the Sierra Madre Oriental; the allochtkon of the High Chain assemblage, Central Plateau between Torreon and San Luis Potosi, Mexico]: Serie Divulgacion no. 1, Institute Geologia UNAM, p. 1-11.

Tipsword, H. L., Fowler, W. A., Jr., and Sorrell, B. J., 1971, Possible future petroleum potential of lower Miocene-Oligocene, western Gulf basin, in Future petroleum provinces of the United States-Their geology and potential: American Association of Petroleum Geologists, Memoir 15, p. 836-854.

Vernon, R. C., 1971, Possible future petroleum potential of preJurassic, western Gulf Basin, in Future petroleum provinces of the United States-Their geology and potential: American Association of Petroleum Geologists Memoir 15, p. 954-979.

Wall, J. R., Murray, G. E., and Diaz, G. T., 1961a, Intrusive gypsum in Coahuila marginal fold belt: American Association of Petroleum Geologists Bulletin, v. 45, p. 1504-1522.

$1961 \mathrm{~b}$, Geology of the Monterrey area, Nuevo Leon, Mexico: Gulf Coast Association Geological Societies, Transactions, v. 11, p. 57-71. 
Weidie, A. E., and Martinez, J. D., 1972, Evaporite diapirism and related problems in the Sierra del Fraile, Mexico: UNESCO Geology of the Saline Deposits, Earth Sciences, no. 7.

Weidie, A. E., and Murray, G. E., 1967, Geology of Parras basin and adjacent areas of northeastern Mexico: American Association of Petroleum Geologists Bulletin, v. 51, p. 678-695.

Weidie, A. E., and Wolleben, J. A., 1969, Upper Jurassic stratigraphic relations near Monterrey, Nuevo Leon, Mexico: American Association of Petroleum Geologists Bulletin, v. 53, p. 2418-2420.

Weidie, A. E., Wolleben, J. A., and McBride, E. F., 1978, Regional geologic framework of northeastern Mexico, in Minas de Golondrinas and Minas Rancherias, Northeastern Mexico: Corpus Christi Geological Society, 1978 Spring Field Conference, p. 27-38.
Weidie, A. E., Wolleben, J. A., and Murray, G. E., 1959, Preliminary report on the structure of the Parras basin in the vicinity of Saltillo, Coahuila, in South Texas Geological Society Guidebook Southeastern Coahuila and Western Nuevo Leon.

Wilson, J. L., and Pialli, G., 1977, A lower Cretaceous shelf margin in northern Mexico, in Cretaceous carbonates of Texas and Mexico: Texas Bureau of Economic Geology, Report Investigation no. 89, p. 286-294.

Young, K., 1977, Middle Cretaceous rocks of Mexico and Texas, in Cretaceous carbonates of Texas and Mexico: Texas Bureau of Economic Geology, Report Investigation no. 89, p. 325-332.

Zwanziger, J. E., 1978, Provincas Mesozoicas productoras en el noreste de Mexico [Mesozoic productive provinces in northeast Mexico]: Ingenieria Petroleras, Marzo de 1979, p. 35-40. 